\title{
Morfología macroscópica de alteración de la piedra de la Catedral de Sevilla, España
}

\author{
Macroscopical morphology of deterioration \\ of the stone in the Cathedral of Seville, Spain
}

\begin{abstract}
RESUMEN
El litotipo mayoritariamente empleado en la construcción de la Catedral de Sevilla es la calcarenita del Puerto de Santa María seguida de la caliza de Espera. El factor extrínseco de alteración primordial es la contaminación atmosférica, principalmente óxidos de azufre y humos, en ambiente húmedo. De ambos factores, piedra porosa de naturaleza carbonatada y medio ambiente ácido, puede deducirse que el principal mecanismo de alteración es el ataque químico y se ha encontrado que los indicadores de alteración más importantes son los depósitos y las arenizaciones.
\end{abstract}

En una valoración a grosso modo puede decirse que la piedra de uso estructural se encuentra bien conservada en su mayor parte, y la ornamental degradada en un $80 \%$. La mitad de las cresterías se encuentran en estado de ruina y un $20 \%$ de los remates han sido retirados 0 habrán de serlo próximamente.

\section{SUMMARY}

The lithotype mainly used in the construction of the Cathedral of Seville is the calcarenite from Puerto de Santa María followed by the limestone from Espera. The primordial extrinsecal factor of deterioration is the atmospherical contamination, mainly sulphur oxides and smoke, within a humid environment. From both factors, the porose stone of a carbonated nature and the acid environment, we can deduce that the principal mechanism of deterioration is the chemical attack; the most important indicators of deterioration that have been found are the deposits and arenizations.

In a "grosso modo" valoration we can say that the stone of structural employment is well conserved in its majority while the ornamental stone is degraded at $80 \%$. Half the cresting is in a state of ruin and $20 \%$ of the tips have been removed or will have to be in the near future.

\section{INTRODUCCIÓN}

La Catedral de Sevilla, el mayor edificio de toda la arquitectura gótica, sólo superado por la basílica de San Pedro del Vaticano y por la de San Pablo de Londres, creó un hito sin precedentes en la arquitectura española. Elementos de la Catedral de Sevilla han quedado reflejados en gran número de iglesias del antiguo Reino de Sevilla y su planta ha sido evocada en las catedrales de Salamanta, Segovia y Valladolid; su influencia saltó a América y su organización pervive en sus grandes catedrales.

\section{INTRODUCTION}

The Cathedral of Seville, the biggest building within all the Gothic architecture, only surpassed by the Basilica of Saint Peter in the Vatican and Saint Paul's in London, created a character without procedents in Spanish architecture. Elements from the Cathedral of Seville have been reflected in a great number of churches in the old Kingdom of Seville and its plans have been suggested in the Cathedrals of Salamanca, Segovia and Valladolid. Its influence was taken to America and its organization still lives amongst their great Cathedrals.

\footnotetext{
* Dpto. de Ingeniería Química y Ambiental.

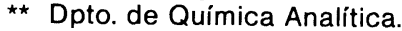


Los terremotos de 1356, 1357 y 1394 habian dejado maltrecha la antigua mezquita almohade que venía haciendo de mezquitacatedral y en un acuerdo capitular de 1401 se decide construir una catedral nueva "tan grande que los que la viesen acabada nos hagan por locos" (manifestación, al parecer, de un canónigo al terminar la sesión del Cabildo). La fecha de colocación de la primera piedra se fija entre 1402 y 1403 y su consagración, sin concluir, tuvo lugar el 11 de mayo de 1507 . Las obras han continuado hasta 1927 , siendo las últimas el labrado de la Portada de la Asunción de la fachada principal, orientada al Norte, y la Puerta de la Concepción que la comunica con el Patio de los Naranjos.

\section{ENTORNO AMBIENTAL}

La Catedral de Sevilla está ubicada en el centro urbano, rodeada de calles y plazas de escaso dimensionamiento, con alta densidad de tráfico y paradas de autobuses. Por el lado Norte se encuentra el Patio de los Naranjos, antiguo atrio de la mezquita. Su dirección longitudinal es de Este a Oeste, siendo su fachada principal la orientada a poniente.

\subsection{Clima}

Sevilla pertenece a la región climática continental atenuada, zona Sur. De las medidas efectuadas por el I. N. de Meteorología, entre los años 1931 y 1980 , se pueden extraer las siguientes conclusiones más importantes:

Las temperaturas son altas gran parte del año, siendo agosto el mes más cálido con una media en sus temperaturas máximas de $35,3^{\circ} \mathrm{C}$. Por el contrario, puede descartarse la influencia de heladas pues el número medio de días al año en que la temperatura mínima es menor de $0^{\circ} \mathrm{C}$ es de 5,7 y solo se han registrado 11 días, en los 50 años, en que la temperatura mínima descendiese por debajo de $-4^{\circ} \mathrm{C}$. Las oscilaciones diarias de temperatura tienen una media a lo largo del año de $13^{\circ} \mathrm{C}$, siendo máximas en julio y agosto con $18^{\circ} \mathrm{C}$.

La humedad relativa media anual es del $68 \%$ alcanzando sus valores máximos en enero y diciembre con una media diaria del $81 \%$ y unos valores punta a las $7 \mathrm{~h}$ del 90 al $95 \%$. El mes más seco es julio, $52 \%$, pero con valores altos por la mañana del 75 al $80 \%$ de media a las $7 \mathrm{~h}$. Las máximas oscilaciones en la humedad relativa, comparando los valores medios a las 7 y a las 13 horas de cada día, se observan en el mes de agosto (80 y $41 \%$
The earthquakes in 1356, 1357 and 1394 had badly damaged the old Almohade Mosque which had been used as a Mosque-Cathedral and, in a capitulary agreement in 1401, it was decided that a new Cathedral "so big that those who contemplated it when finished would think us mad" (statement, so it seems, made by a canon at the end of a chapter council meeting) be built. The first stone was laid between 1402 and 1403 and its consecration, without being finished, took place $11^{\text {th }}$ May 1507. Work was continued until 1927 and the sculptures on the Portada de la Asuncion of the main façade, oriented to the North, and the Puerta de la Concepción which communicates with the Patio de los Naranjos were the last built.

\section{ENVIRONMENTAL SURROUNDINGS}

The Cathedral of Seville is located in the centre of the city, surrounded by narrow streets and small squares with a high density of traffic and bus stops. On the Northern side is the Patio de los Naranjos, the old atrium of the Mosque. Its linear direction is from East to West while its main façade West.

\subsection{Climate}

Seville belongs to the attenuated continental climatic region, Southern area. The most important data, obtained from readings taken by the National Institute of Meteorology between 1931 and 1980 are as follows:

The temperatures are high during a great part of the year, August being the hottest month with an average maximum temperature of $35,3^{\circ} \mathrm{C}$. On the other hand, the influence of frosts can be discarded as the average number of days per year in which the minimum temperature is less than $0^{\circ} \mathrm{C}$ is 5,7 and only on 11 days in 50 years has the temperature been lower than $-4^{\circ} \mathrm{C}$. The daily oscillations of temperature (maximum-minimum) have an average of $13^{\circ} \mathrm{C}$ during the year, July and August being the months of maximum average oscillation at $18^{\circ} \mathrm{C}$.

The average yearly relative humidity is $68 \%$ reaching a maximum of $81 \%$ in January and December and top values of 90 to $95 \%$ at 7 o'clock in the morning. The driest month is July, at $52 \%$, yet with high values of 75 to $80 \%$ at 7 o'clock in the morning. The maximum oscillations in relative humidity, comparing the averages at 7 a.m. and 1 p.m. every day, take place in August (80 and $41 \%$ respectively) and the minimum in January (92 and $71 \%$ ). 
respectivamente) y las mínimas en enero (92 y $71 \%)$.

La precipitación media anual es de $585 \mathrm{l} / \mathrm{m}^{2}$, pero repartidos en tan sólo 80 días de lluvia intensa al año. Enero y marzo son los meses con una media pluviométrica más alta, $82 \mathrm{l} / \mathrm{m}^{2}$, y julio con la más baja, $1 \mathrm{l} / \mathrm{m}^{2}$. Entre 1922 y 1980 ha nevado en 12 ocasiones en cantidades inapreciables.

Los vientos dominantes son del SO y $\mathrm{O}$ durante todo el año y algunos del NE en invierno. La velocidad media anual es de $10 \mathrm{~km} / \mathrm{h}$ y en general no se superan los $50 \mathrm{~km} / \mathrm{h}$.

\subsection{Contaminación}

Los focos emisores de productos contaminantes del aire más importantes son los siguientes:

En primer lugar por los motores de combustión interna, principalmente automóviles, al ser Sevilla una ciudad de trazado antiguo con calles estrechas, y por no haber existido restricción alguna al tráfico en los alrededores de la Catedral durante mucho tiempo. También es importante cierta industrialización, tanto artesanal y antigua (fundiciones, cerámicas, etc.) como de nueva creación (fábricas de abonos, de productos químicos, etc.) que, aunque situadas en el extrarradio, por su proximidad y por la dirección de los vientos, dejan sentir su influencia contaminante sobre la ciudad. El puerto fluvial dispone de muelles de atraque muy cercanos al centro de la ciudad, donde se realizan faenas de carga y descarga de materiales muy diversos, a veces con producción de polvo. Puede mencionarse también como foco contaminante el propio clima de la ciudad que, por la frecuencia de fenómenos de inversión térmica, con humedad y temperaturas altas, favorece el desarrollo de reacciones químicas secundarias.

Podemos destacar los siguientes valores de inmisión de diversos contaminantes en la zona de la Catedral:
The average yearly rainfall is $585 \mathrm{l} / \mathrm{m}^{2}$, however these are spread over only 80 days of intense rainfall per year. January and March are the mosths with the highest average pluviometry, $82 \mathrm{l} / \mathrm{m}^{2}$, and July the lowest with $1 \mathrm{l} / \mathrm{m}^{2}$.

Between 1922 and 1980 it has snowed on 12 occasions with insignificant quantities.

The dominant winds are from SW and $W$ all through the year and some from NE in Winter. The average yearly wind-speed is $10 \mathrm{~km} / \mathrm{h}$ and, in general, they are not above $50 \mathrm{~km} / \mathrm{h}$.

\subsection{Pollution}

The most important emitting sources of air pollution are as follows:

In first place, the internal combustion engine, mainly the automobiles, as Seville is an old town with narrow streets having had no restrictions for a long time at all for the traffic which circulates around the Catedral. A certain artesanal and ancient industrialization (foundries, ceramics, etc.) as well as the recently created ones (fertilizer plants, chemical plants, etc.) are also important, these which, although situated on the outskirts, make their contaminating influence felt on the city due to their proximity and the wind direction. The fluvial port has its quays very near the city centre, where materials of different kinds are loaded and unloaded, sometimes producing a lot of dust. The climate of the city itself can be mentioned as a focal point of contamination which, because of thermic inversion phenomenon, high temperature and humidity favour the development of secondary chemical reactions.

The following immission values of contaminants in the Cathedral area are outstanding:

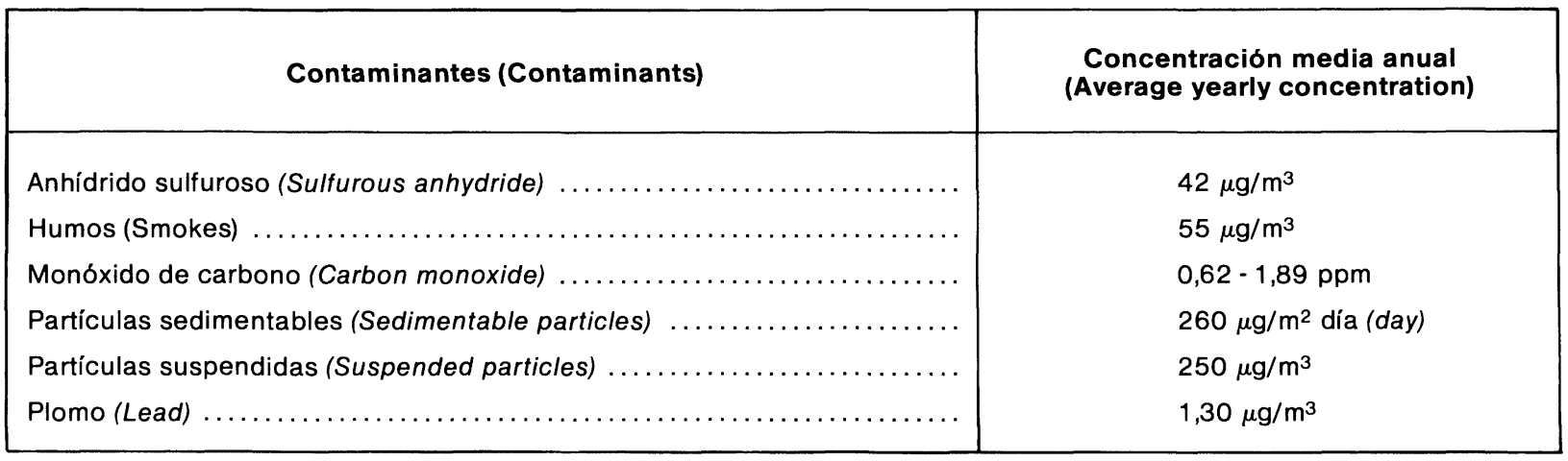


La Avenida de la Constitución, situada al poniente de la Catedral, es la más contaminada, lo que está de acuerdo con la mayor densidad de tráfico que registra en comparación con las demás que rodean al edificio. Con fines comparativos se han tomado medidas de anhídrido sulfuroso y humos en dicha avenida (64 y $49 \mu \mathrm{g} / \mathrm{m}^{3}$ ) y en la Plaza Virgen de los Reyes, situada al oriente (47 y $21 \mu \mathrm{g} / \mathrm{m}^{3}$ ) que corroboran dicha afirmación.

\subsection{Subsuelo}

Es importante también reseñar que la situación topográfica del edificio, prácticamente a nivel del mar, hace que la capa freática se encuentre cerca de los cimientos, lo que origina la presencia de una importante humedad ascendente que afecta, sobre todo, a los muros de la fachada Sur.

\section{MATERIALES PÉTREOS}

Como era común en los edificios góticos, en la Catedral de Sevilla se empleó preferentemente la piedra como material de construcción, lo cual planteó serios obstáculos, no sólo por carecer Sevilla de canteras en zonas próximas sino, consecuentemente, por no existir en ella tradición gremial en el corte de la piedra. Aun cuando en los archivos de la Catedral y en la bibliografía sobre el tema se mencionan más de veinte canteras suministradoras, estudios de identificación de materiales bastante exhaustivos realizados por nuestro equipo de investigación, han podido determinar que la piedra mayoritariamente utilizada es una calcarenita fosilífera de grano grueso procedente de las canteras del Cerro de San Cristóbal del Puerto de Santa María (Cádiz).

Le sigue en orden de importancia una caliza, también fosilífera y de grano más fino, procedente de Espera (Cádiz), sobre todo en elementos intercalados con la anterior en las cresterías; también se ha utilizado como principal elemento de construcción en los Archivos, volumen bajo que, lamentablemente, se adicionó a la Catedral en la fachada Sur en 1918.

Otras piedras de menor implantación son las procedentes de Estepa, Utrera, Morón, etc., utilizadas en zócalos, tracerías, restauraciones, etc. Las portadas de la Concepción y del Príncipe, en las fachadas Norte y Sur respectivamente, han sido realizadas a finales del XIX y principios del XX con piedra procedente de Monóvar (Alicante) según la documentación catedralicia (Falcón, 1980),
The Avenida de la Constitucion, situated to the West of the Cathedral is the most contaminated, in agreement with the higher density of traffic registered here than in the others which surround the building. Measurements of smoke and sulfurous anhydride in the cited avenue (64 and $\left.49 \mu \mathrm{g} / \mathrm{m}^{3}\right)$ and in the Plaza Virgen de los Reyes (47 and $21 \mu \mathrm{g} / \mathrm{m}^{3}$ ) situated to the East, have been taken for comparison and to confirm the above.

\subsection{Subsoil}

It is also important to stress that the topographical location of the building, practically at sea level, means the freatic layer is found near the foundations. This originates the presence of an important rising damp which affects, above all, the walls of the Southern façade.

\section{PETREUS MATERIALS}

As was common in Gothic buildings, stone was preferably used as construction material in the Cathedral of Seville which presented serious obstacles not only for the lack of quarries nearbl but, as result of this, the inexistence of a guisdsman tradition in stone-cutting. Even though more than twenty supply quarries are mentioned in the bibliography and in the Cathedral archives, the exhaustive studies carried out by our research team on the identification of materials have been able to determine that the stone mainly used is a fossiliferous thick grained calcarenite from the quarries of Cerro de San Cristóbal at Puerto de Santa María (Cádiz).

The second stone in importance is a thinnergrained, fossiliferous limestone from Espera (Cádiz) which was, above all, intercalated with the former in the crestings. It was also used as the main material in the construction of the Archivos, a low building which was lamentably added on the Southern façade of the Cathedral in 1918.

Other stones that were used to a lesser extent are those from Estepa, Utrera, Morón, etc., in socles, traceries, restorations, etc. The Portadas de la Concepción and del Príncipe, on the Northern and Southern façades respectively, were built at the end of the nineteenth and the beginning of the twentieth centuries with stone from Monóvar (Alicante) according to Cathedral documents (Falcón, 
aunque se han sugerido otros orígenes (Esbert, 1988).

Quizás deba también mencionarse que sobre el 1880 empezó a utilizarse el cemento Portland; a veces mezclado con polvo de mármol para las esculturas.

La caracterización química, petrográfica y estructural de gran parte de estos materiales se encuentra ampliamente documentada (Alcalde, 1984 y 1990; Bello, 1988; Esbert, 1988; Villegas, 1990).

\section{MORFOLOGÍA MACROSCÓPICA DE LAS ALTERACIONES}

Se hará una descripción por fachadas, comenzando por la Principal o de Poniente. Dentro de cada fachada, tras unas consideraciones previas acerca de los litotipos existentes, clima, urbanismo, ambiente y agentes biológicos, se hace una descripción de los indicadores visuales de alteración, siguiendo un criterio ordenado en el cual se estudian las modificaciones superficiales, disyunciones, deformaciones, eliminaciones de materia y rupturas, empleando para ello los términos sistematizados por los autores (Martín, 1990).

\subsection{Fachada Principal}

La piedra utilizada en esta fachada pertenece casi exclusivamente al litotipo del Puerto de Santa Maria. Por tanto, cabe esperar que actuarán como factores de alteración intrínsecos los característicos de las calcarenitas de grano grueso y alta porosidad. También se ha utilizado cemento Portland mezclado con polvo de mármol en la portada central, tanto en la decoración escultórica del tímpano como en la mitad inferior de los baquetones y columnillas de los contrafuertes y en el arco de entrada. Las restauraciones efectuadas en nuestro siglo en las portadas laterales también son de cemento. Las figuras son de tarracota.

Contrariamente a lo que cabría esperar en uno de los monumentos góticos más importantes del mundo, su fachada principal no está precedida de una amplia explanada sino por una calle que la generosidad ha venido en llamar Avenida, aunque no es posible alcanzar siquiera una separación suficiente que permita fotografiarla en toda su extensión. Un intenso tráfico rodado, sin limitación alguna durante muchos años y ahora levemente restringido, hace que el aire esté altamente contaminado por óxidos de azufre e inquemados.
1980), although other origins have been suggested (Esbert, 1988)

Perhaps it should also mention that Portland cement began to be used around 1880 sometimes mixed with marble dust for the sculptures.

The chemical, petrographical and structural characterization of a great deal of these materials is widely documented (Alcalde, 1984 \& 1990; Bello, 1988; Esbert, 1988; Villegas, 1990).

\section{MACROSCOPICAL MORPHOLOGY OF THE DETERIORATIONS}

A description of each façade will be made starting with the Main or Western one. After some previous comments about the existing lithotypes, climate, urbanism, environment and biological agents, a description of the visual indicators of deterioration, following an orderly criteria, will be given in which the superficial modifications, disjunctions, deformations, elimination of material and ruptures are studied, using the sistematised terminology of the authors (Martin, 1990).

\subsection{Main Façade}

The stone used on this façade belongs almost exclusively to the lithotype of Puerto de Santa Maria. Therefore we expect that the thick-grained, highly porose calcarenites will act as intrinsical factors of deterioration. Portland cement mixed with marble dust has also been used in the sculptural decoration of the tympanum as well as the lower half of the moulding of the abutments and the entrance arch the central portal. The restorations made in our century on lateral portals are also cement. The figures are in terra cotta.

Contrary to would be expected in one of the most important Gothic monuments in the world, there is no spacious explanade in front of the main façade. Yet there is a street wich is generously called an Avenue although it is not wide enough to photograph the street in all its length. The intense traffic, which for many years had no restriction and even nowadays has very few, makes the air highly contaminated by sulphuric oxides and unburnt materials. 
Por estar orientada a poniente, recibe el agua de las Iluvias cuya mayor frecuencia coincide con vientos dominantes del Sudoeste. La humedad ascendente, como ya se ha explicado, alcanza gran altura en esta fachada.

El estado de conservación en general no es malo, pues la costra superficial que estos litotipos alcanzan con el paso del tiempo los hace resistentes a la agresión del medio ambiente. No obstante, los depósitos de materia carbonosa son abundantes y se encuentran distribuidos discrecionalmente; por un lado son mayores cuanto más cerca se encuentran del nivel del suelo, de forma que las zonas altas, más alejadas de los focos emisores y más batidas por los vientos, están limpias (Figura 1 a). Por otro lado, las superficies orientadas al exterior presentan mayores depósitos que las interiores, como muestran las Figuras 1 c y d, correspondientes al mismo antepecho en sus dos orientaciones.

Las zonas húmedas, debajo de las cornisas, con mayor abundancia en el desarrollo de agentes biológicos, también fijan mejor los inquemados y aparecen más ennegrecidos (Figura 1 b). Las zonas protegidas de la lluvia, que no reciben los efectos de lavado de las mismas coincidentes con los vientos dominantes del Sudoeste también presentan mayores deposiciones; las Figuras 1 e y f corresponden a la misma zona en ambas orienaciones. Este fenómeno se hace patente en los edículos cilíndricos de las escaleras, donde las zonas lavada y resguardada aparecen perfectamente diferenciadas (Figura 2 a).

No pueden dejar de mencionarse dentro de los depósitos superficiales los abundantes excrementos de palomas, sobre todo en la portada de la Asunción o Principal, en cuyos recovecos hay incluso nidos. Unos finos hilos de nylon, convenientemente colocados, podrían evitar con sencillez este problema al dificultar el vuelo de las palomas.

Normalmente la formación de depósitos, sobre todo cuando éstos han adquirido consistencia por el desarrollo de microorganismos, lo que les lleva a veces también a ser impermeables, suele ir acompañada de la disyunción de los mismos. Esto puede producirse principalmente de dos formas: como películas, en cuyo caso ciclos rápidos de humidificación y secado producen el despegamiento y separación de los depósitos (Figura 2 b), o bien en forma de placas, en aquellos lugares en que el agua tiene mayor tiempo de residencia y se produce el ataque químico del material subyacente. El depósito, rico en elementos metálicos catalizadores, favorece la oxidación del anhidrido sulfuroso por lo que la solución
Due to its orientation to the West it receives rainwater which usually coincides with the dominating South Easterly winds. The rising damp, as has already been explained, reaches a greath eight on this façade.

The general state of conservation is not bad as the superficial crusting that these lithotypes reach the passing of time makes them resist the attacks from the environment. However, the deposits of carbonaceous material are abundant and they are distributed discretionally; on one hand they are bigger as they get closer to ground level, so the higher areas being further away from the focal points and more windswept are cleaner (Figure 1 a). On the other hand, the surfaces oriented to the exterior have greater deposits than those oriented to the interior, as Figures $1 \mathrm{c}$ and $\mathrm{d}$ show, corresponding to the same parapet in both its orientations.

The humid areas such as underneath the cornices with a greater abundance in the development of biological agents are where the unburnt materials settle better and are more blackened (Figure $1 \mathrm{~b}$ ). The areas protected from the rain, which do not receive the washing effect of the former when coinciding with the dominating South Westerly winds, also show greater deposits;

Figures 1 e \& $f$ correspond to the same area in both orientations. This phenomenon is more obvious in the cylindrical niches of the stairway where the sheltered and washed areas are clearly differentiated (Figure 2 a).

The abundant sea-bird dung has to be mentioned within the superficial deposits, especially on the Portada de Asunción or the main one, in whose bends there even nests. Some conveniently placed fine nylon nets could easily avoid this problem by making the flight of sea-birds difficult.

Normally the formation of deposits, above all when these have become consistent due to the development of micro-organisms which sometimes make them impermeable, are usually acompanied by disjunctions of these. This can happen mainly in two ways: as films, in which case the rapid cycles of humidification and drying produce the dettachment and separation of deposits (Figure 2 b) or as plaques, in those places where water remains for a longer period and a chemical attack on the underlying material is produced. The deposit, rich in catalysing metallic elements, favours the oxidation of the sulfurous anhydride so the sulphuric solution attacks the carbonates of the cement 


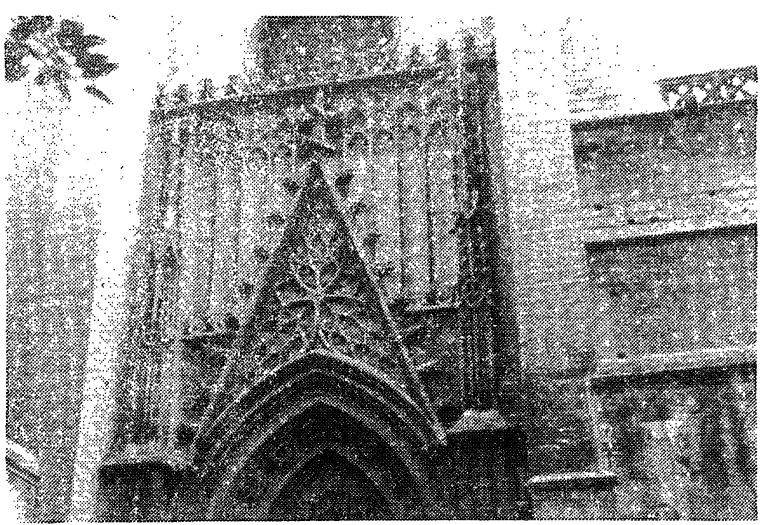

a) Distribución de los depósitos según la altura.

a) Distribution of deposits according to height.

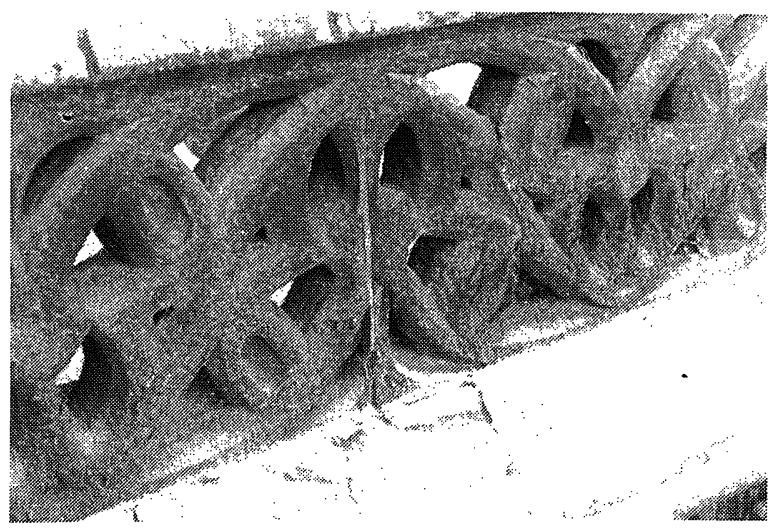

c) Mayores deposiciones en superficies orientadas al exterior.

c) Greater depositions on surfaces oriented to the exterior.

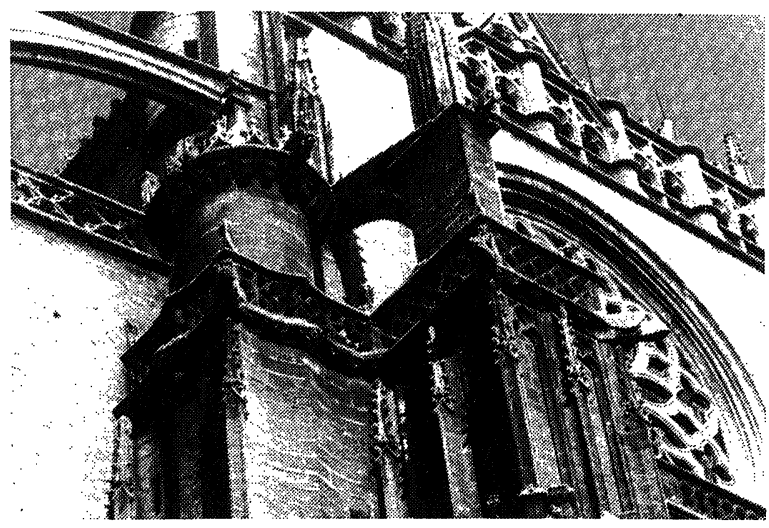

e) Mayores deposiciones en superficies orientadas al Norte.

e) Greater depositions on surfaces oriented to the North.

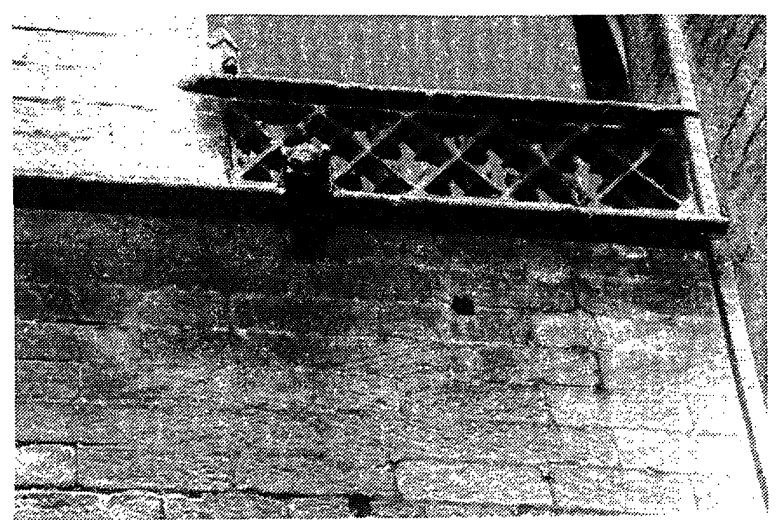

b) Aumento de los depósitos debajo de las cornisas.

b) Increase in deposits underneath the cornices.

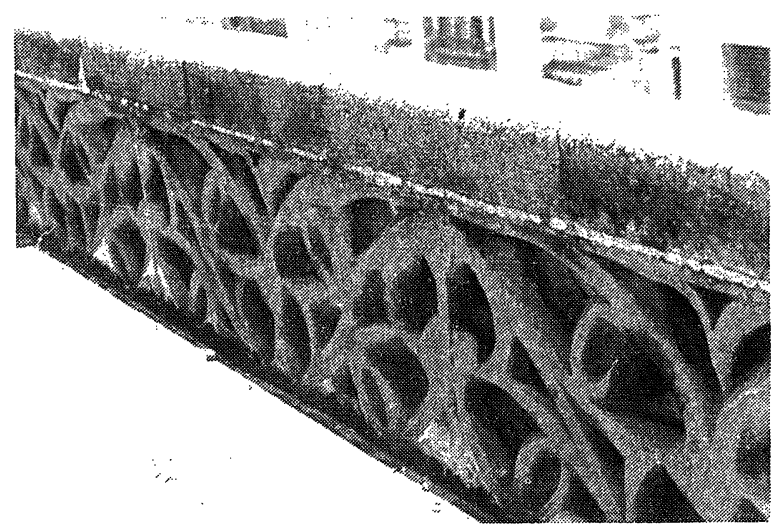

d) Menores deposiciones en superficies orientadas al interior.

d) Lesser depositions on surfaces oriented to the interior.

Figura 1.-Indicadores visuales de alteración. Fachada Principal. 1. lámina.

Figure 1.-Visual indicators of deterioration. Main Façade 1. ${ }^{\text {nd }}$ picture. 


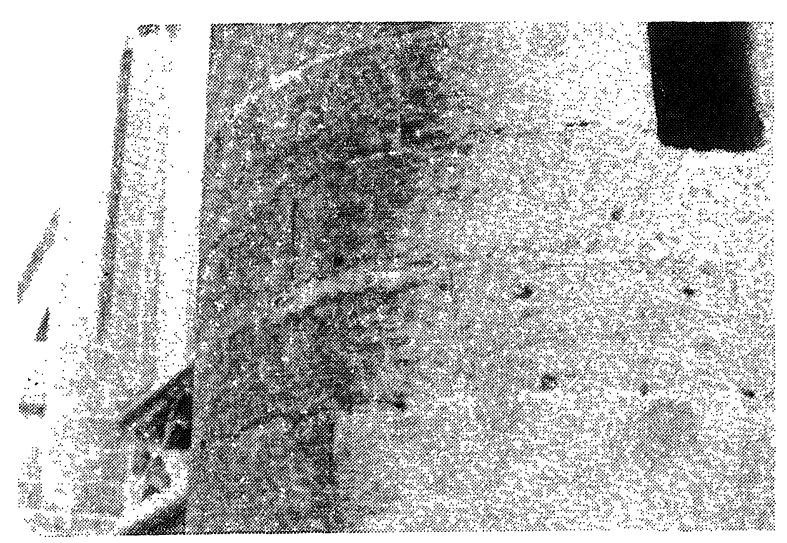

a) Deposiciones según la orientación.

a) Depositions according to orientation.

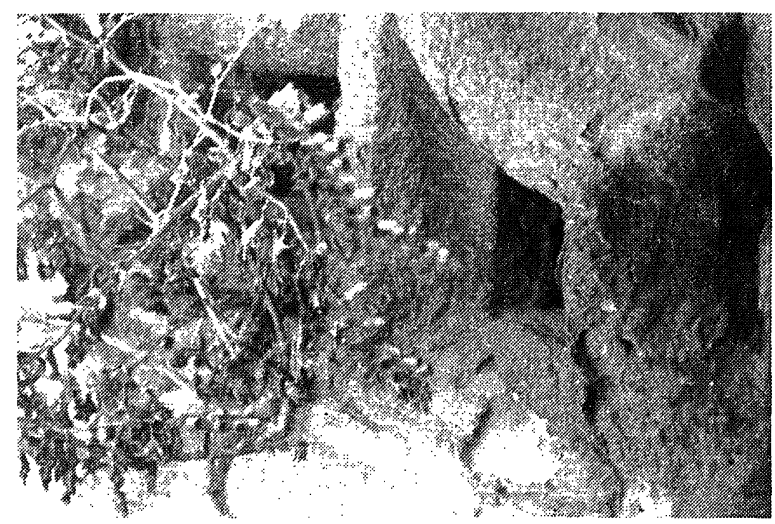

c) Disyunciones de placas.

c) Contour scaling.

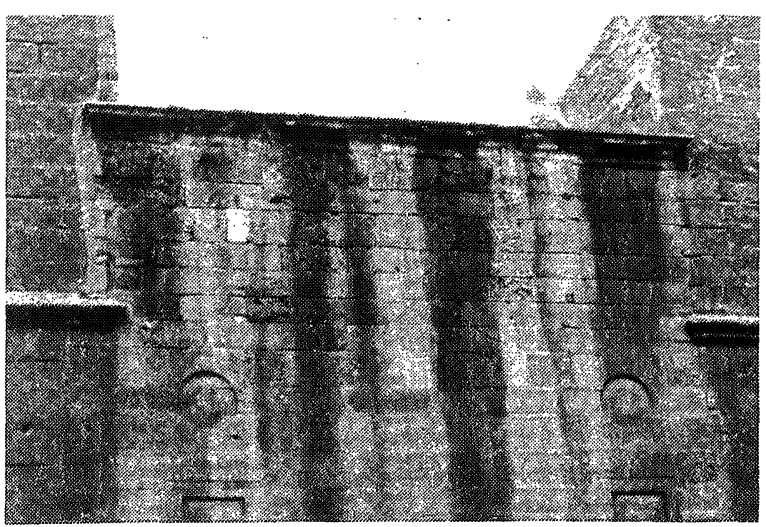

e) Picaduras y alveolizaciones en las zonas húmedas y más aireadas.

e) Pitting and alveolar erosion on wet and windswept areas.

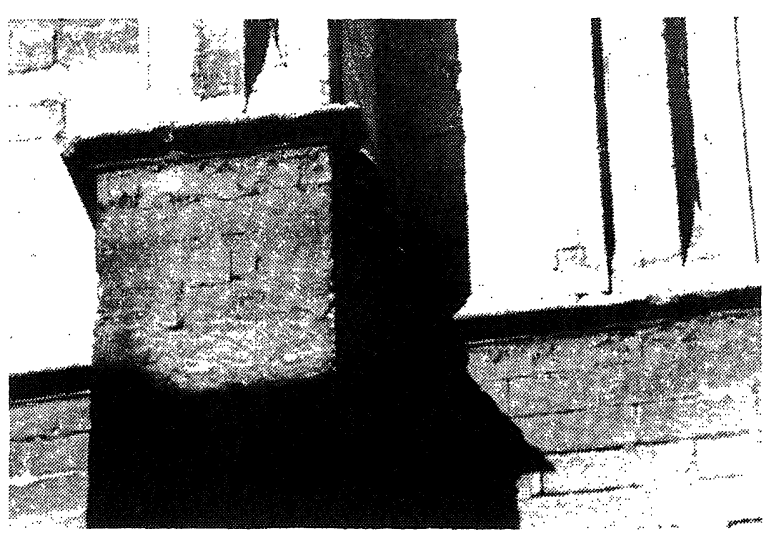

b) Disyunciones de películas.

b) Films disjunctions.

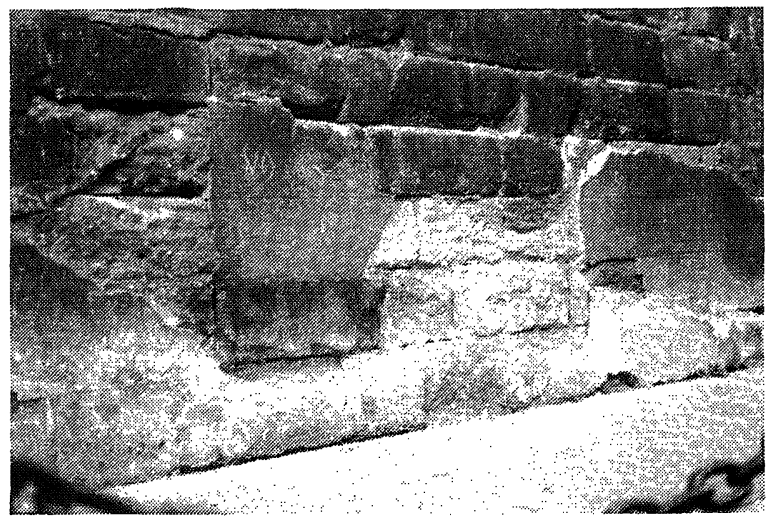

d) Arenizaciones por humedad ascendente y por morteros.

d) Arenizations due to rising damp and mortar salts.

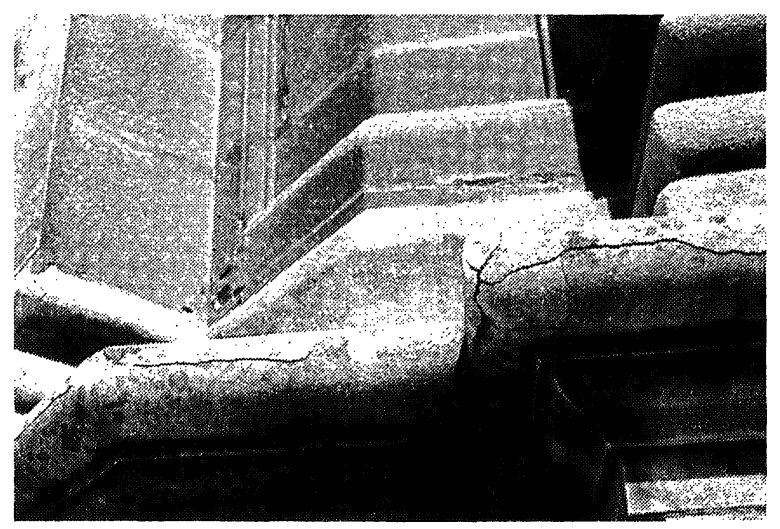

f) Fisuras en el cemento de las portadas.

f) Fissuring on cement of the front.

Figura 2.-Indicadores visuales de alteración. Fachada Principal. 2." lámina.

Figure 2.-Visual indicators of deterioration. Main Façade. $2 .^{\text {.nd }}$ picture. 
de sulfúrico formada ataca a los carbonatos del cemento produciéndose la decohesión de los granos. La piedra suele quedar arenizada y el depósito se desprende con parte de la misma, como una placa de cierto espesor que adopta la forma de la superficie base, sin relación a planos de estratificación (Figura 2 c).

Otras decohesiones debidas a ciclos de cristalización de sales se dan en las zonas afectadas por la humedad ascendente, al nivel de la calle hasta un metro de altura. La gran porosidad de estas piedras permite un fácil ascenso de las soluciones salinas procedentes del subsuelo hasta cristalizar en la superficie de la piedra. Dado que los morteros entre bloques constituyen un paso preferencial, en ellos se hacen más intensos estos mecanismos provocando la arenización del material y el consiguiente redondeamiento de los ángulos de los sillares. Este fenómeno suele engendrar un círculo vicioso de factores de alteración; con objeto de ocultar los anteriores indicadores de alteración, se aplican morteros a veces ricos en sales que, además de no evitar el factor de alteración causante, constituyen una fuente que realimenta los ciclos de cristalización; el mortero termina separándose de la pared arrastrando gran parte del material subyacente (Figura 2 d).

La humedad combinada con el viento da lugar a los picados. Si el viento arranca material disgregado en un punto, en el hueco formado se produce un aumento de la velocidad del aire (remolino) lo que conduce a la aceleración del proceso de alteración y a la formación de un agujero o picadura. Según la porosidad de la piedra, la distancia a la fuente de humedad y la exposición al viento, el fenómeno puede llegar a convertirse en alveolización (Figura 2 e).

Los elementos decorativos como pináculos, cresterías y gárgolas, que en otras fachadas suelen presentar erosión y corrasión, en ésta se conservan bastante bien.

La piedra del Puerto de Santa Maria, que asume bien los cambios de temperatura y que no presenta problemas de tensiones residuales, no suele padecer rupturas. Algunas fisuras parecen ser debidas a problemas de cargas del edificio o de terremotos. Sin embargo, donde sí se presentan tanto fracturas y fisuras como disyunciones que van desde escamas a grandes placas, es en el moderno material que tanta ilusión despertó en el XIX, el cemento Portland (Figura 2 f). Se desconoce el origen de unos pequeños agujeros existentes junto a los practicados para andamios, pero su forma recuerda producing decoherence of the grains. The stone is usually arenized and the deposit falls off with a part of the same in plaque-form of a certain thickness, with the form of the element surface, without conection to the stratification plains (contour scaling) (Figure 2 c).

Other decoherences due to the salt crystallization cycles are found in areas affected by rising damp, from street level to a metre in height. The great porosity of these stones permits an easy ascent of salt solutions from the soil until they crystallize on the surface of the stone. Given that the mortars between blocks constitute a preferential way, the mechanisms in them are made more intense and provoke the arenization of the material and consequently the rounding off of the angles of ashlars. The phenomenon usually originates a vicious circle of deterioration factors; mortars rich in salts were applied with the object of hiding the anterior indicators of deterioration which, besides not avoiding the causing factor of deterioration, constituted a source which feeds the cycles of crystallization. The mortar finishes up by separating itself from the wall and dragging down a large part of the underlying material (Figure $2 d$ ).

The humidity combined with the wind gives rise to pitting. If the wind tears off disaggregated material at one point in the gap formed an increase in air-speed (whirlwind) is produced which leads to the acceleration in the deterioration process and the formation of a hole or pitting. The phenomenon can become alveolar erosion depending on the porosity of the stone, the distance from the source of humidity and wind exposure. (Figure 2 e).

The decorative elements such as pinnacles, cresting and gargoyles, which on other façades usually present erosion and corrasion, are on this quite well conserved.

The stone from Puerto de Santa María, which endures the temperature changes well and does not present problems of residual tensions, does not suffer from ruptures. Some fissures seem to be problems of stress in the building or by earthquakes. However, where cracks and fissures as well as disjunctions, which go from scales to large plaques, are seen is in the modern material which gave rise to so many hopes in the XIX century, Portland cement (Figure $2 f$ ). The origins of some small holes which exist next to those used for scaffolding is unknown, but their shape reminds us exactly of those produced by 
perfectamente los producidos en otros templos por ametrallamientos, como en la Catedral de Almería.

En resumen, la alteración más característica de esta fachada, así como la más llamativa por su repercusión antiestética, es el ennegrecimiento producido por depósitos superficiales de inquemados, que afecta a toda ella de forma heterogénea. Son especialmente graves los depósitos debajo de las cornisas, en las esculturas y en los antepechos, donde favorecen los mecanismos de corrosión que conducen a arenizaciones y disyunciones de placas.

\subsection{Fachada Sur}

En nuestros días se han ultimado las dos dependencias destinadas a archivos y oficinas, adosadas al flanco Sudoeste, construidas con calizas de Espera. La portada del Príncipe, comenzada en 1887 , se construyó con una caliza oolítica muy compacta que algunos autores atribuyen a Monóvar (Falcón, 1980) y otros a Estepa (Esbert, 1988). Para el resto de la fachada se ha utilizado mayoritariamente calcarenita del Puerto de Santa María, sobre todo en lo que se refiere a la parte estructural; en las cresterías aparecen intercalados elementos labrados en piedras de Espera. En los zócalos de la esquina Sudoeste aparece una arenisca, probablemente de Morón, y el zócalo y las pilastras del lienzo Sudeste son de una caliza de aspecto pizarroso, tal vez de Utrera.

La piedra del Puerto de Santa María, al igual que en la fachada Principal, presenta una buena resistencia a los factores extrínsecos de alteración, mientras que la de Espera, con valores muy heterogéneos de porosidad, muestra alteraciones muy diferentes de unos sillares a otros, incluso cuando están sometidos a los mismos factores extrínsecos. La caliza oolítica, de reciente colocación, se conserva bien, salvo que presenta en su superficie un gran desarrollo de agentes biológicos, sobre todo líquenes; no obstante, muchos de los remates de pináculos, de restauración reciente, se encuentran completamente degradados.

En cuanto al medio ambiente, esta fachada, orientada al Sur, es la más expuesta al sol, al tiempo que recibe las aguas de lluvia coincidentes con vientos del Sudoeste; por este motivo, es posible encontrar en ella zonas soleadas y umbrias, lavadas y protegidas, aireadas y resguardadas. En invierno son frecuentes las nieblas, así como las condensaciones en la superficie de la piedra. El aire se encuentra contaminado por machine guns in other temples such as the Cathedral of Almeria.

In summary, the most characteristic deterioration of this facade as well as being the most outstanding for its unsightliness, is the blackening produced by superficial deposits of unburnt materials which affects all of it heterogeneously. The deposits underneath the cornices, on the sculptures and parapets are especially serious where the mechanisms of corrasion, which lead to arenizations and contour scalings, are favoured.

\subsection{Southern Façade}

In our days the two outbuildings for archives and offices which are joined to the Southern façade have been built and finished with limestone from Espera. The Portada del Príncipe, started in 1887, was built with a very compact oolitic limestone that some authors attribute to Monóvar (Falcón, 1980) and others to Estepa (Esbert, 1988). Calcarenite from Puerto de Santa María has been mainly used for the rest of the façade, especially in the structural part. Figures in stone from Espera appear intercalated in the cresting. A sandstone, probably from Morón, appears in the socles of the South Eastern corner while a slate-like limestone, perhaps from Utrera, appears in the socles and pilasters of the South Eastern face.

The stone from Puerto de Santa Maria, the same as on the main façade, presents good resistance to the extrinsecal factors of deterioration while that of Espera, with very heterogeneous values of porosity, shows very different deteriorations between ashlars even when they are exposed to the same extrinsecal factors. The oolitic limestone, recently laid, is well conserved except that it presents a large development of biological agents on its surface, above all lichens; however, many of the recently-restored tips of the pinnacles are completely debased.

As for the environment, this façade oriented to the South is exposed to the sun and receives reinwater which usually coincides with the South Easterly winds. For this reason it possible to find sunbasked and shaded areas, rainwashed and protected areas and aired and sheltered ones. Fogs are frequent in Winter as are the condensations on the stone's surface. The air is contaminated by combustion products from the traffic in the area, especially 
los productos de combustión del tráfico de la zona, sobre todo por las paradas de autobuses donde a veces se producen densas nubes de humo.

Esta gran variedad de factores de alteración, tanto intrínsecos como extrínsecos, hacen que esta fachada se constituya en un verdadero muestrario de indicadores de alteración de piedras sedimentarias donde sólo faltan, lógicamente en esta ciudad, los debidos a heladicidad.

El litotipo del Puerto de Santa María presenta una costra endurecida que la hace bastante inerte al medio ambiente, con un cambio de coloración hacia tonos más grises y oscuros. Esta costra se forma también en la de Espera, incluso con una pátina más oscura aún, pero con peor resultado frente al medio, como se verá. En general se observan tinciones por óxidos de hierro en las superficies barridas por agua procedentes de clavos y rejas. En zonas resguardadas existen depósitos negros de materia carbonosa y, en el caso de patios interiores y otras superficies alejadas de la calle y protegidas por volúmenes altos, estos depósitos son sólo de polvo, de color marrón. La orientación también tiene una marcada influencia en las deposiciones, como queda de manifiesto en el volumen que queda a la derecha de la portada del Príncipe, en que la superficie orientada al atrio está limpia mientras que la orientada al Archivo de Indias está mucho más ennegrecida. Dentro de este capítulo de depósitos, apenas tienen importancia las eflorescencias, aunque algunas pueden observarse bajo las cornisas de los Archivos y Oficinas.

El desarrollo de colonias de líquenes ofrece en la caliza oolítica un típico moteado y franjas ennegrecidas en las superficies barridas por agua, como debajo de las gárgolas, No obstante, el mayor crecimiento de agentes biológicos se da, lógicamente, en las superficies más húmedas y resguardadas. Así, es posible encontrar costras biológicas, muy adherentes y endurecidas por concreciones, en superficies que reciben el agua por percolación, como es debajo de las barandas (Figura 3 a); almohadillas de musgos, poco coherentes y negras, en las zonas más umbrias (Figura 3 b); películas de materia carbonosa cohesionada por microorganismos (Figura $3 \mathrm{c}$ ). Por último, no faltan plantas superiores, como en algunas gárgolas.

Cuando los fenómenos de disyunción afectan solo a estas películas, el material subyacente queda inalterado (Figura $3 \mathrm{c}$ ), pero lo más corriente es la separación de placas que dejan la superficie arenizada (Figura $3 \mathrm{~d}$ ). A veces este hecho viene precedido por la formación from the bus-stops where thick clouds of smoke are sometimes produced.

This great variety of deterioration factors, intrinsical as well as extrinsical, makes this facade a real collection of deterioration indicators of sedimentary stones where only, logically in this city, the one due to freezing is missing.

The lithotype from Puerto de Santa Maria presents a hardened crust which makes it quite inert to the environment, with a change in colouring towards greyer and darker tones. This crust is also formed on the one from Espera with an even darker patina but with worse results in the environment as will be seen. In general staining by iron oxides are observed on the surfaces swept by water from the nails and grates. In sheltered areas black deposits of carbonaceous material exist, and in the case of the inside courts and other surfaces protected by high buildings and far from the street, these deposits are only brown dust. The orientation has a marked influence on the deposits as is manifest in the building to the right of the Portada del Principe on which the surface facing the atrium is clean while the one facing the Archivos de Indias is much more blackened. Within this chapter on deposits the efflorescencies have hardly any importance although some can be seen underneath the cornice of the Archives and Offices.

The development of colonies of lichens gives the oolitic limestone typical spotting and blackened borders on the surfaces swept by rain, just as under the gargoyles. However, the greater growth of biological agents is logically found on the more humid and sheltered surfaces. So, it is possible to find biological crusts, very adhesive and hardened by concretions, on surfaces which receive percolated water such as under the bannisters (Figure 3a); cushions of moss, not very coherent and black, in the more shaded areas (Figure 3b); films of carbonaceous material stuck together by micro-organisms (Figure 3c). Finally, higher plant life is not lacking such as on some gargoyles.

When disjunction affects only these films, the underlying material remains undeteriorated (Figure $3 \mathrm{c}$ ) but contour scaling is the most common phenomenon which laeves the surface arenized (Figure $3 \mathrm{~d}$ ). Sometimes this is preceded by blistering which finally bursts. 


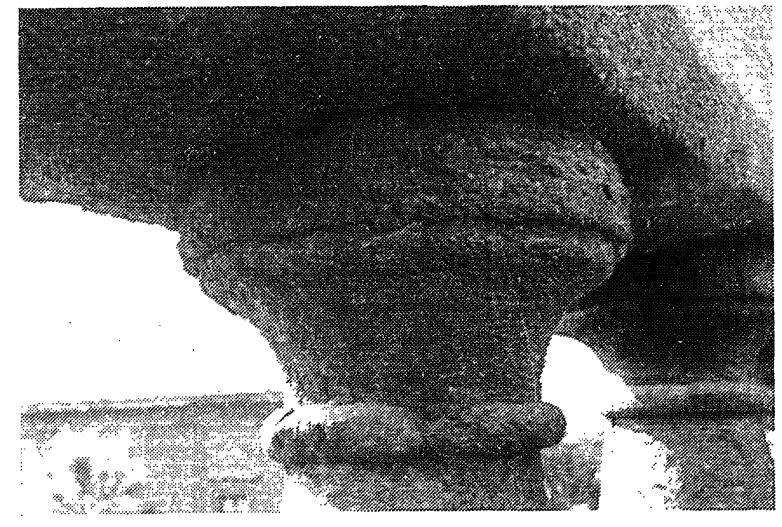

a) Costras biológicas.

a) Biological crusts.

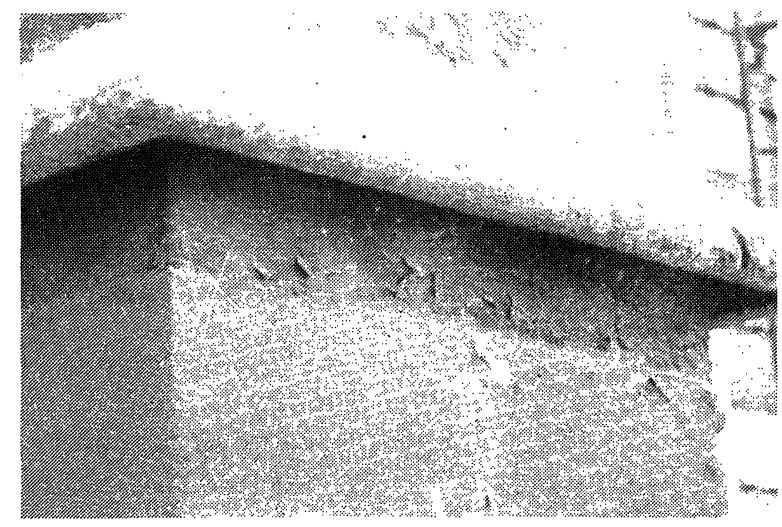

c) Disyunciones de películas.

c) Film disjunctions.

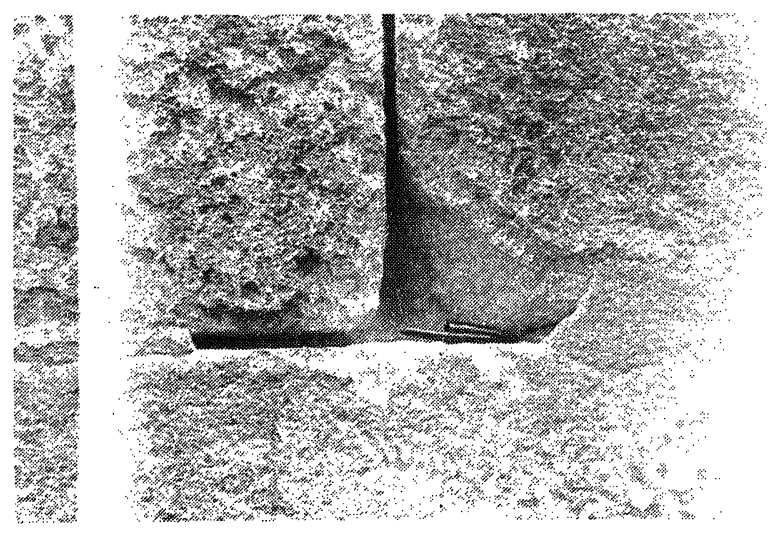

e) Arenizaciones inducidas por el uso de morteros.

e) Arenizations broughton by the employment of mortars.

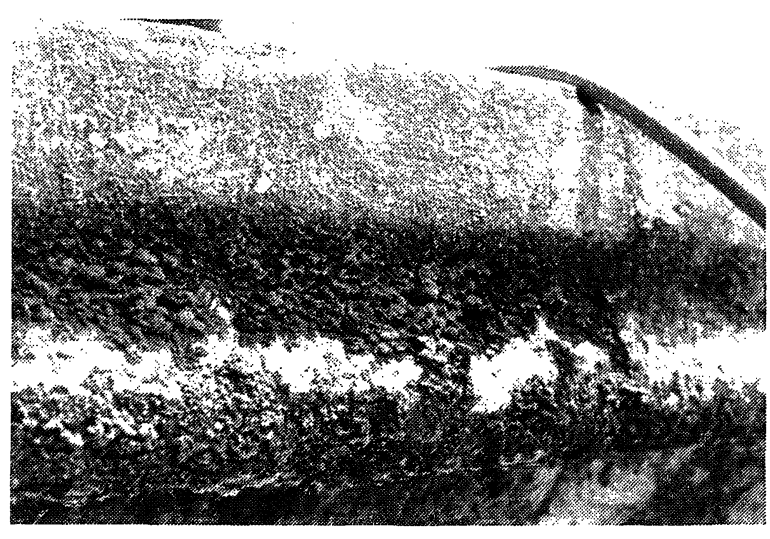

b) Depósitos de musgo.

b) Deposit of moss.

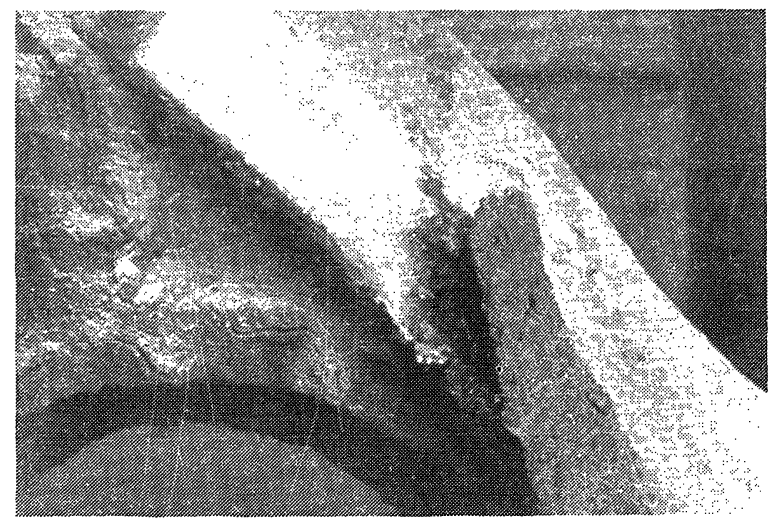

d) Disyunción de placas y arenización.

d) Contour scaling and arenization.

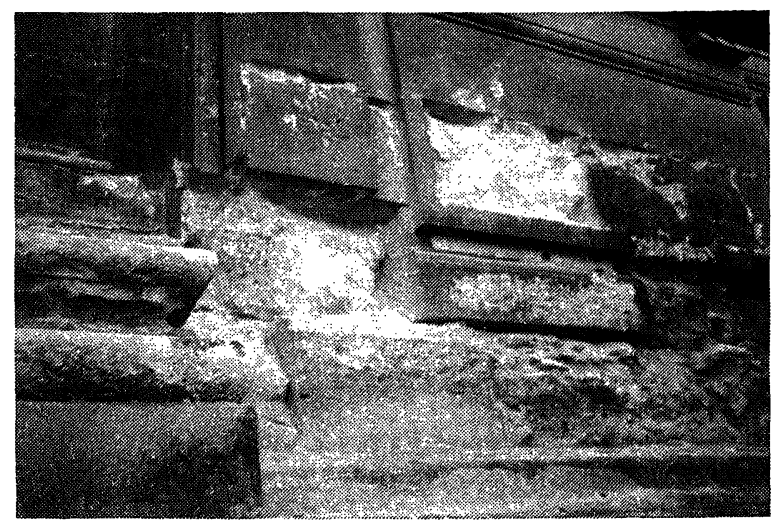

f) Diversos grados de decohesión en la caliza heterogénea de Espera.

f) Decoherences gradation on the heterogeneous limestone from Espera.

Figura 3.-Indicadores visuales de alteración. Fachada Sur. 1. Iámina.

Figure 3.-Visual indicators of deterioration. Southern Façade. $1 .{ }^{\text {st }}$ picture. 
de ampollas que terminan estallando. Aunque en las piedras de Espera se dan algunas alteraciones con apariencia de exfoliaciones, donde éstas aparecen de forma generalizada es en las calizas pizarrosas del zócalo del muro de cerramiento de la Sacristía Mayor. La caliza oolítica de la portada presenta algunas descamaciones.

Los mecanismos de alteración conducentes a decohesiones afectan de modo muy diferente a la calcarenita del Puerto, de porosidad grande pero uniforme, que a las calizas de Espera, de porosidad muy variable, sobre todo cuando ambas ejercen funciones estructurales. Las primeras sólo presentan fenómenos de decohesión acompañada de arenizaciones, en presencia de factores fuertemente inductores de ciclos de cristalización, como es el caso del uso de morteros ricos en sales (Figura 3 e). Por el contrario, los segundos responden de una manera diferencial, probablemente según la porosidad; en la Figura 3 f puede verse como, junto a sillares bien conservados se encuentran otros completamente arenizados, así como situaciones intermedias. No obstante, todos quedarán uniformados dentro de poco; téngase presente que fueron instalados hace tan sólo setenta años y que la evolución del proceso es francamente rápida, como muestran las fotografías de las Figuras 4 a y b, tomadas en el mismo lugar en el intervalo de diez años.

Los elementos con funciones ornamentales (balaustradas, cresterias, pináculos, etc.), al haber sufrido la pieda un mayor labrado ofrecen una mayor superficie de exposición al ambiente por lo que presentan un mayor grado de alteración en ambos tipos de piedra; no obstante, también corresponden al tipo de Espera los elementos más arenizados, por lo que no es extraño ver, junto a adornos más o menos bien conservados, otros completamente destruidos o incluso desaparecidos.

En los paramentos se observa que al ganar altura aparece un ligero picado en las proximidades de las cornisas. Este fenómeno se da en mayor grado en las superficies más aireadas, en donde pueden darse incluso alveolizaciones. La contribución del viento a esta alteración se hace evidente en los pináculos (Figura 5 b) y en los flameros de las balaustradas en que las superficies orientadas hacia el Sudoeste, de donde proceden los vientos dominantes, presentan picado y alveolización, mientras que las opuestas son lisas o incluso presentan depósitos. También se observan alveolizaciones en la pizarra del zócalo de la Sacristía Mayor, sobre todo en las
Although some peeling-like deteriorations are found in the stone from Espera these generally appear in slaty limestone on the socle of the enclosing wall of the Main Sacristy. The oolitic limestone of the portal show some chipping.

The deterioration mechanisms leading to decoherences affects the calcarenite from the Puerto de Santa Maria, of a high but uniform porosity, in a different way to the limestones from Espera, of a very variable porosity, above all when both exercise structural fuctions. The former only shows decoherence accompanied by arenizations in the presence of inductive factors of crystallization such as in the case of the use of mortars rich in salts (Figure $3 e$ ). On the othe hand the latter responds with differential deterioration, probably depending on porosity; in Figure $3 f$ it can see how completely arenized ashlars are found next to well conserved ones as well as intermediate ones. However, all off them will be the same in a short while; bear in mind that they were only installed sixty years ago and the evolution of process is frankly rapid, as the photographs, taken in the same place with an interval of then years, show in Figures $4 a \& b$.

The stone with ornamental functions (balaustrades, cresting, pinnacles, etc.) having undergone more cutting offers a greater surface of exposure to the environment and so presents a greater degree of deterioration in both types of stone; however those corresponding to Espera are arenized so it is not strange to see completely destroyed ornaments next to others which are more or less well conserved or some which have completely disappeared.

In the paraments it can observe that as we go higher a slight pitting underneath the cornices appears. This phenomenon takes place on a greater scale on the more aerated surfaces where even alveolar erosions can take place. The contribution of winds to this deterioration is evident in the pinnacles (Figure $5 \mathrm{~b}$ ) and in the torch-holders on the balaustrades in which the surfaces facing South East, where the dominating winds come from, show pitting and alveolar erosion while the opposite ones are smooth even present deposits. Alveolar erosions are also seen on the slate of the socle of the Main Sacristy, above all on the corners (Figure 4c) and in the sandstone from 


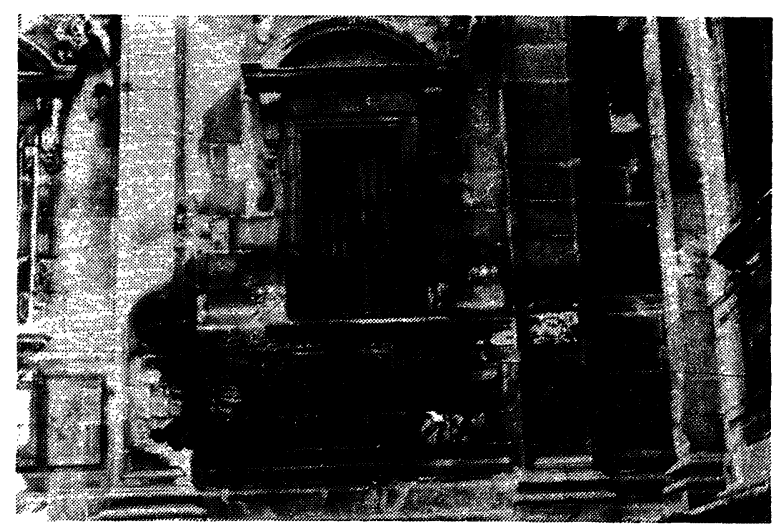

a) Estado de un lienzo de caliza de Espera en mayo de 1978.

a) State of a face of limestone from Espera in May 1978.

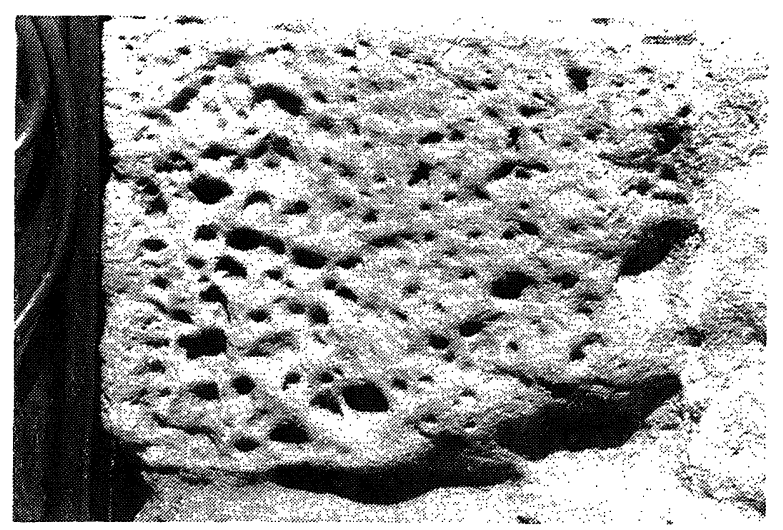

c) Alveolización en zócalos húmedos y aireados.

c) Alveolar erosion on wet and windswept socles.

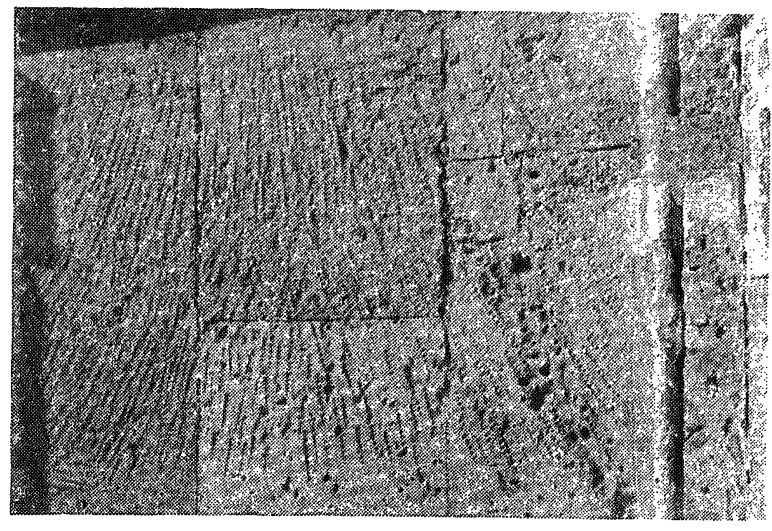

e) Excoriaciones de causa desconocida.

e) Excoriations of unknown origin

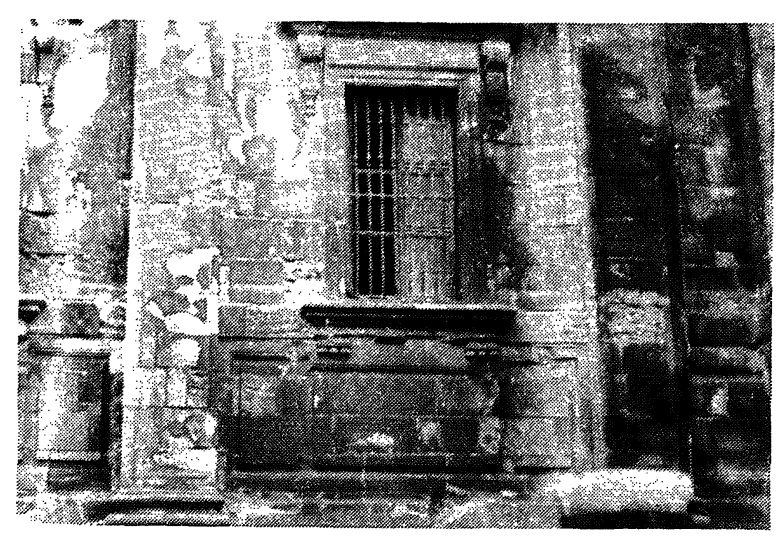

b) Estado del mismo lienzo anterior en Enero de 1988.

b) State of the same face in January 1988.

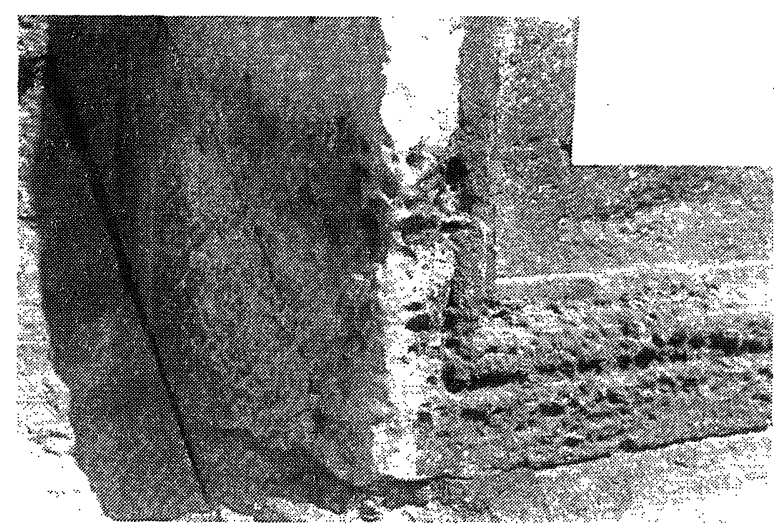

d) Formación de cavernas en zócalos húmedos y de piedra muy porosa.

d) Crater formations on wet socles of porous stone.

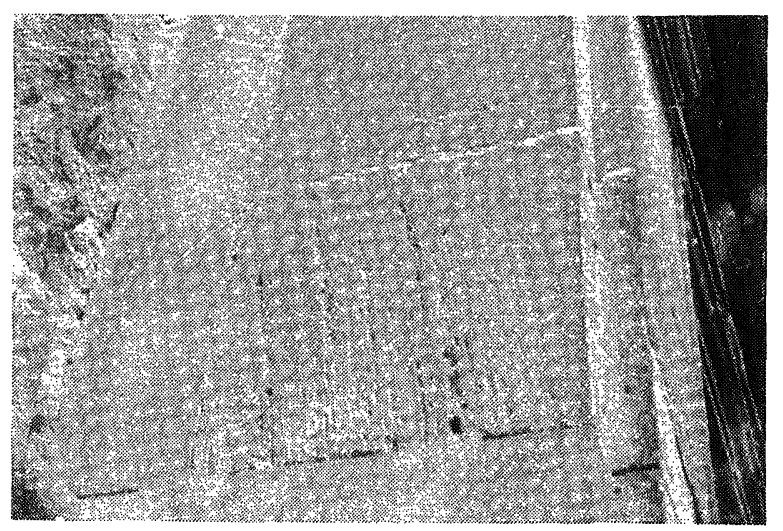

f) Estriado en un sillar con los lechos colocados verticalmente.

f) Striation on an ashlar with vertical stratums.

Figura 4.-Indicadores visuales de alteración. Fachada Sur. 2. ${ }^{a}$ lámina.

Figure 4.-Visual indicators of deterioration. Southern Façade. 2. ${ }^{\text {nd }}$ picture. 
esquinas (Figura $4 \mathrm{c}$ ), y en las areniscas de Morón en que a veces se llega a cavernizaciones (Figura $4 \mathrm{~d}$ ).

Como es lógico, las cresterías de los niveles más altos, y en especial los remates que las adornan, así como los pináculos, son los elementos donde se localizan las erosiones y corrasiones, que son más graves cuando la piedra es de Espera.

Las excoriaciones y estriados no están muy extendidos pero pueden encontrarse algunos ejemplos (Figuras 4 e y f).

Son indicadores de alteración importantes en esta fachada las rupturas, tanto fracturas y fisuras como fragmentaciones, importancia que nace de la gran cantidad de episodios que se dan y de la gravedad de sus consecuencias. La mayor parte están producidos por la expansión de hierros embutidos en la piedra, como barandas y rejas (Figura 5 a) y, sobre todo, como espigas de sujeción de pináculos (Figura 5 b) y de flameros (Figura $5 \mathrm{c}$ ), y que al oxidarse se expanden haciéndola estallar. La pérdida de fragmentos ha obligado en ocasiones a acordonar la zona ante el riesgo de daño a los peatones, así como al empleo de alambres de sujeción de los pináculos y flameros para evitar su caída a la calle (Figura $5 \mathrm{c}$ ), o bien a su demolición (véase la evolución en dos años en las Figuras 5 e y f).

También se dan otras rupturas, esta vez por el efecto combinado de la naturaleza de la piedra, una caliza mucho más compacta, y los ciclos de cristalización de sales, o bien de hidratación y secado. Es el caso de las calizas blancas del muro de cerramiento del flanco sudoriental. Es interesante el estudio de tres pilastras con abundantes fracturas, fisuras $y$ fragmentaciones, donde además se dan pulverizaciones (Figura 5 d) en comparación con las restantes en este lienzo, bien conservadas. Las primeras son las que se corresponden precisamente con el Patio del Mariscal, mientras que las restantes lo hacen con dependencias cubiertas; esto hace pensar en una migración de humedad hacia el exterior de esta soleada fachada.

En resumen, al estar bien lavada por la lluvia, esta fachada presenta un aspecto más limpio que las demás, excepto en los volúmenes bajos. Las alteraciones más importantes son, en primer lugar, las arenizaciones en los muros de los Archivos y Oficinas, en franca progresión con el tiempo y que dan un aspecto general de degradación a esta parte de la fachada; las abundantes pérdidas de material en elementos de las cresterias que han llevado a la pérdida de algunos de ellos $y$,
Morón in which they sometimes turn into crater formations (Figure $4 d$ ).

As is logical, the crestings at higher levels and especially the crowns that adorn them as well as the pinnacles are the elements where erosions and corrasions are located, being more serious when the stone comes from Espera.

The excoriations and striation are not very widespread but some examples can be found (Figures $4 e \& f$ ).

The ruptures, so cracks and fisures as spalling are important indicators of deterioration on this facade, an importance which arises from the great quantity of incidents given and the seriousness of their consequences. Most of them are produced by expansion of the inlaid iron in the stone, such as railings and grates (Figure $5 \mathrm{a}$ ) and above all, as spike holders of the pinnacles (Figure 5b) and torch-holders (Figure 5c) which on expanding make it explode. The loss of spalls has sometimes made the authorities cordon the area because of the risk of injury to pedestrians and employ holding wires on the pinnacles and torch-holders to avoid these falling into the street (Figure 5c) or their demolition (see the evolution over two years in Figures $5 e \& f$ ).

Other ruptures also take place, this time due to the combined effect of the nature of the stone, a much more compact limestone, and the salt crystallization or hydratation and drying cicles. This is the case of the white limestone in the enclosing wall of the South Eastern wing. The study of three pilasters with abundant cracks, fissures and spalling, where pulverization also takes place, is interesting compared to the rest in this stretch of wall which is well conserved. The former are those which correspond precisely to the Patio del Mariscal while the rest correspond to the covered dependences; this makes us think of a migration of humidity towards the exterior of this sunlight façade.

In summary, as this facade is well washed by the rain it presents a cleaner appearance than the others except in the low buildings. The most important deteriorations are, in the first place, the arenizations in the wall of the Archives and Offices in undisguised progression within time and which give a general appearance of degradation on this part of the façade; the abundant losses of material in the cresting has led to the loss of some of them and, finally, the cracking and fissuring 


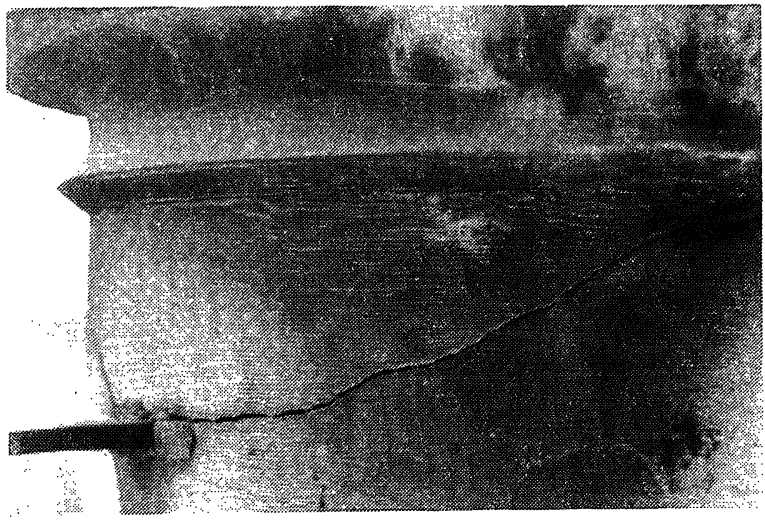

a) Fisuración producida por expansión de hierros al oxidarse.

a) Fissuring by the oxidation and expansion of iron.

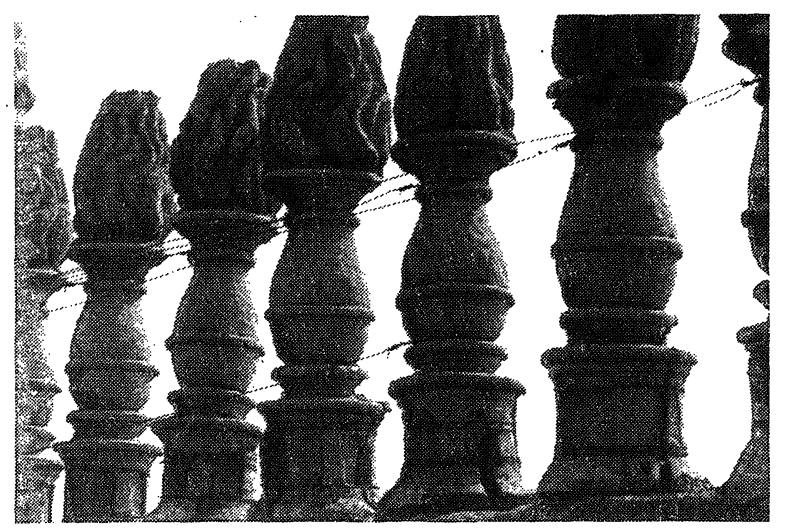

c) Ruptura total de la base de los flameros con espigas metálicas.

c) Total rupture of the torch-holder foots with metal spikes.

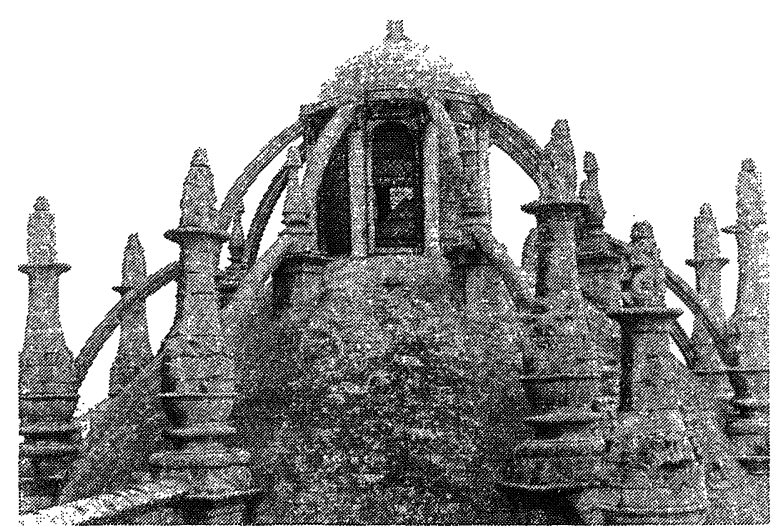

b) Diversas rupturas por oxidación de las espigas metálicas de sujeción.

b) Several ruptures by oxidation of metallic spike.

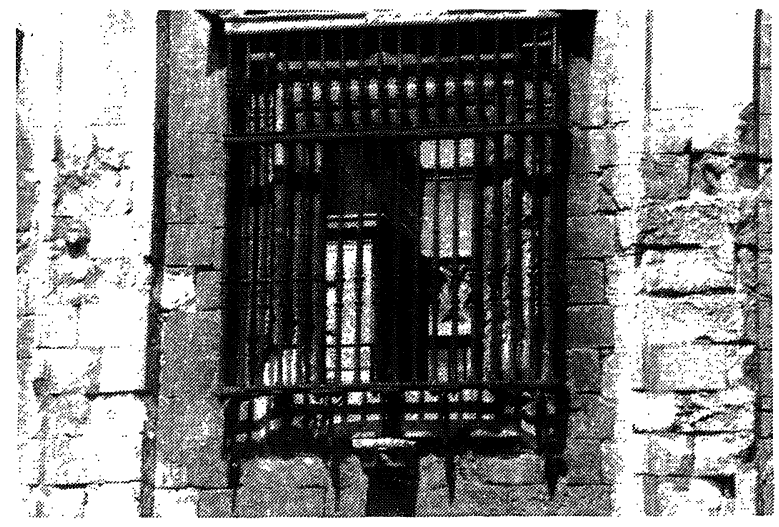

d) Rupturas, disgregaciones y pulverizaciones en ciertas pilastras.

d) Ruptures, disintegrations and pulverizations on some pilasters.

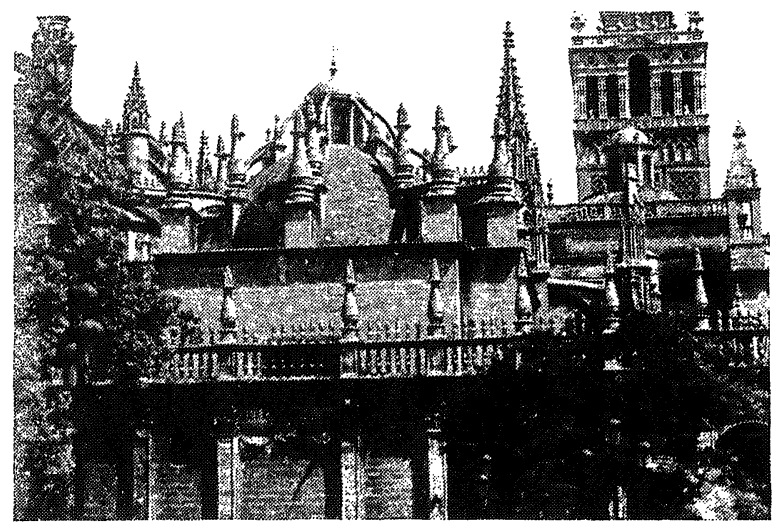

e) Estado de los flameros en Marzo de 1985

e) State of the torch-holders in March 1985

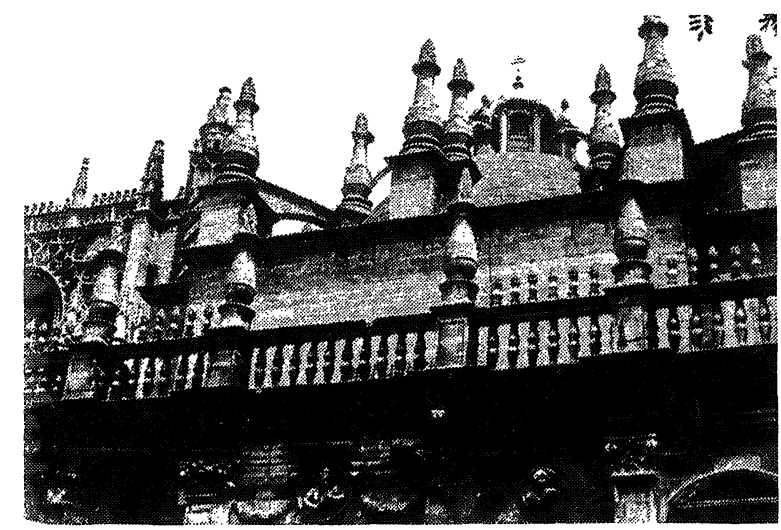

f) Estado de los flameros en Julio de 1987.

f) State of the torch-holders in July 1987.

Figura 5.--Indicadores visuales de alteración. Fachada Sur. 3. 'ámina.

Figure 5.-Visual indicators of deterioration. Southern Façade. $3 .^{\text {th }}$ picture. 
por último, las fracturaciones y fisuraciones originadas por la oxidación de espigas de sujeción de flameros y pináculos.

\subsection{Fachada Este}

Como en el resto del edificio, la piedra mayoritariamente empleada es la del Puerto de Santa María, con elementos intercalados, sobre todo en cresterías y pináculos, de piedras de Espera. El zócalo de las puertas de Campanillas y de Palos probablemente sea de Morón. Una caliza compacta, blanca y bien conservada, de origen no determinado, se ha utilizado en gárgolas, zócalos y restauraciones.

Por su orientación al Este, esta fachada sólo recibe el sol durante la mañana y resulta poco lavada por las lluvias coincidentes con los vientos dominantes del Sudoeste. Más húmeda que las anteriores, presenta también mayor desarrollo de agentes biológicos, sobre todo en la parte del muro del ábside adyacente a la puerta de Palos, verde en invierno y negra en verano.

La plaza Virgen de los Reyes que antecede a esta fachada tiene un alto tráfico rodado, sin restricción y con acceso libre incluso a los autocares, por lo que el ambiente está contaminado por los productos de combustión.

Los depósitos de materia carbonosa se distribuían con criterios similares a los comentados en la fachada Principal, pero en los últimos años se han llevado a cabo tareas de limpieza con la aplicación de una capa de color marrón de composición no determinada, sobre la cual aparecen algunas eflorescencias.

Los fenómenos de disyunción con arenización asociada, consecuentes de la aplicación de morteros en tareas de restauración, se presentan sobre todo en las juntas entre sillares del muro de la Sala Capitular y Contaduría (Figura 6 a).

Los antepechos de los distintos niveles sufren grandes pérdidas de material. Los factores intrínsecos, fundamentalmente la alta porosidad y el carácter calizo del cemento de la piedra, se conjugan aquí con los extrínsecos, como la humedad, condensaciones, óxidos de azufre, agentes biológicos, metales catalíticos en los depósitos, de tal modo que los mecanismos de ataque ácido, disolución, cristalización, han conducido a que las arenizaciones afecten al interior de la piedra, llevando a ésta a un estado de ruina que se desmorona a trozos (Figura 6 b). Este estado de ruina afecta a los cuatro remates de la Figura 6 c (de 1984), tres originated by the oxidation of the spike-holders of the torch-holders and pinnacles.

\subsection{Eastern Façade}

As in the rest of the building the main stone used is the one from Puerto de Santa Maria with intercalated materials from Espera, especially in the crestings and pinnacles. The socles of the Campanillas and Palos gates are probably from Morón. A compact, white and well-conserved limestone of unknown origin was used for the gargoyles, socles and restorations.

Due to its Easterly orientation this façade receives the sun only in the morning and it is little washed by the South Westerly rains. More humid than the previous one it presents a greater development of biological agents, above all in the stretch of Presbitery wall adjacent to the Palos gate being green in Winter and black in Summer.

The Virgen del Rocio square in front of this façade has a high volume of traffic, with no restrictions and free access even for coaches, so that the environment is contaminated by combustion products.

The deposits of carbonaceous material were distributed with similar criteria to those on the main facade, but over the last few years cleaning has been carried out, with the application of a coating of an indetermined brown-coloured composition upon which some efflorescencies have appeard.

The phenomena of disjunction with associated arenization, a consequence of the application of mortars in restoration workare seen, above all, in the joints between ashlars in the Sala Capitular and Contaduría wall (Figure 6a).

The parapets at different levels undergo severe losses of material. The intrinsical factors, the porosity of the stone and the calcareous character of his cement, are connected here with the extrinsecal ones such as humidity, condensations, sulphur oxides, biological agents and catalytic metals in the deposits. So, the acid attack, dissolution and crystallization mechanisms have led to a great deepness of the arenizations and a state of ruin that it disintegrates in pieces (Figure 6b). This ruinous state affects the four tips of Figure $6 \mathrm{c}$ (1984), three of which do not now exist (Figure 6d, 1987); Figure 6 e shows the state of the remaining the other one. Other 


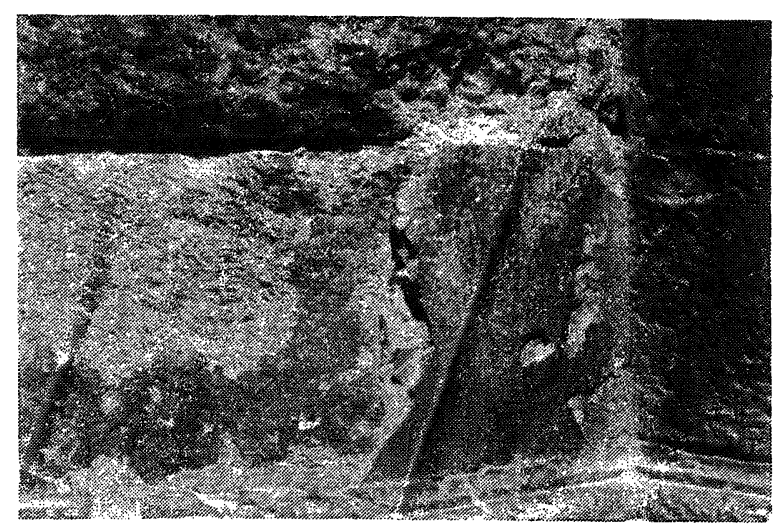

a) Disyunciones y arenizaciones por el uso de morteros.

a) Disjunctions and arenizations due to employment of mortar.

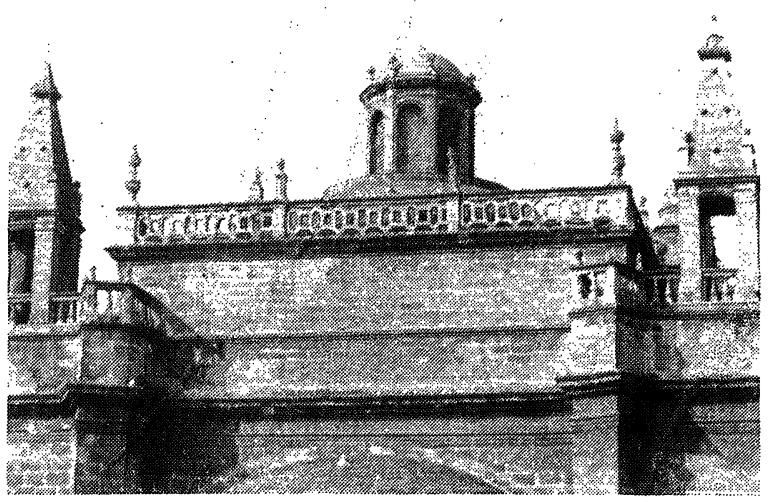

c) Estado de los adornos de un antepecho en octubre de 1984.

c) State of the parapet ornaments in October 1984.

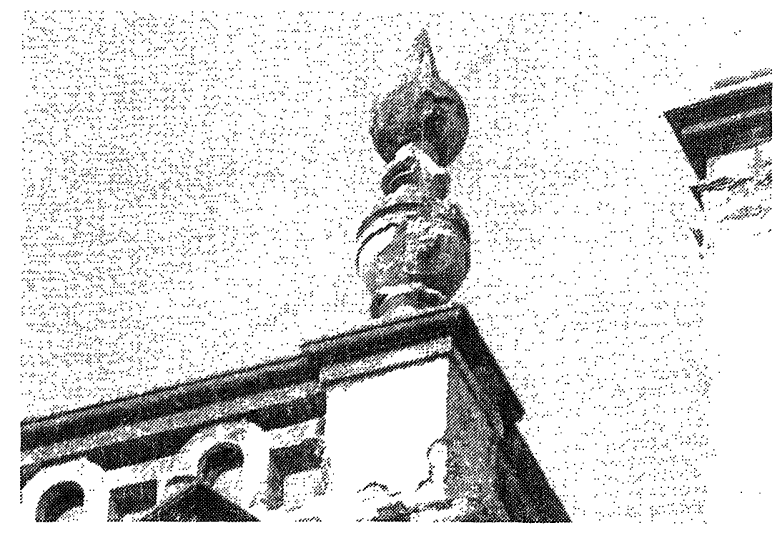

e) Estado degradado del último adorno que queda en el antepecho anterior.

e) Degradation state of the last ornament rest on former parapet.

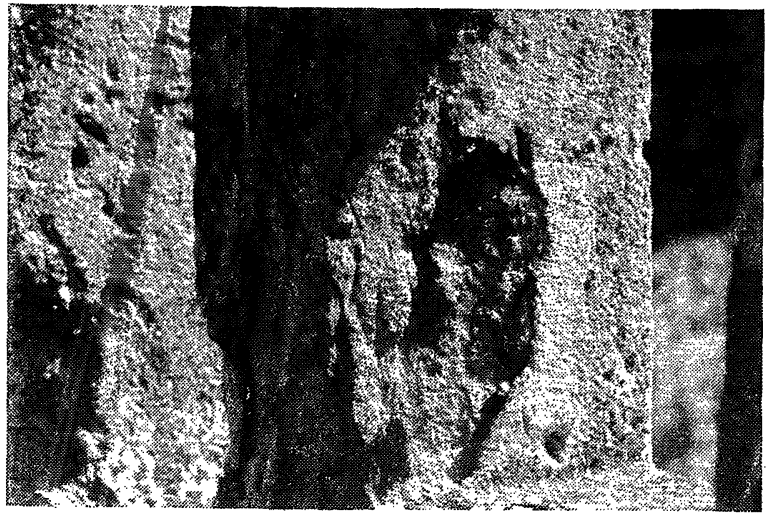

b) Estado de ruina: por arenizaciones profundas en antepechos.

b) Ruin state by deep arenizations on parapets.

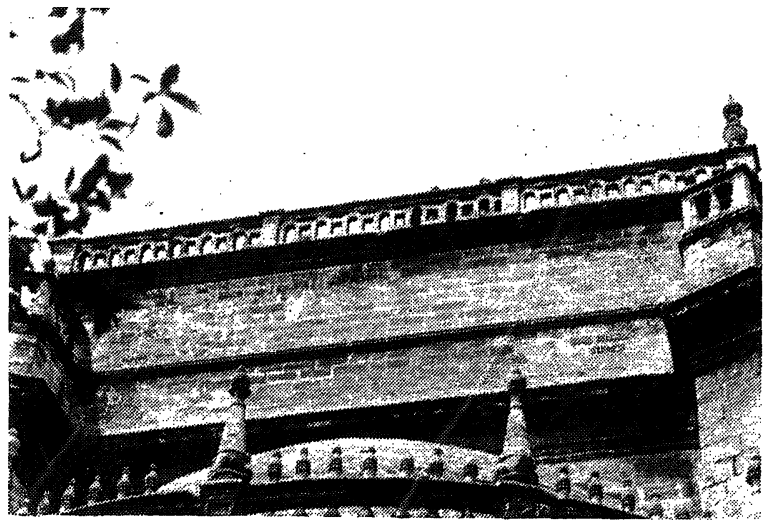

d) Estado de dicho antepecho en julio de 1987.

d) State of the same parapet in July 1987.

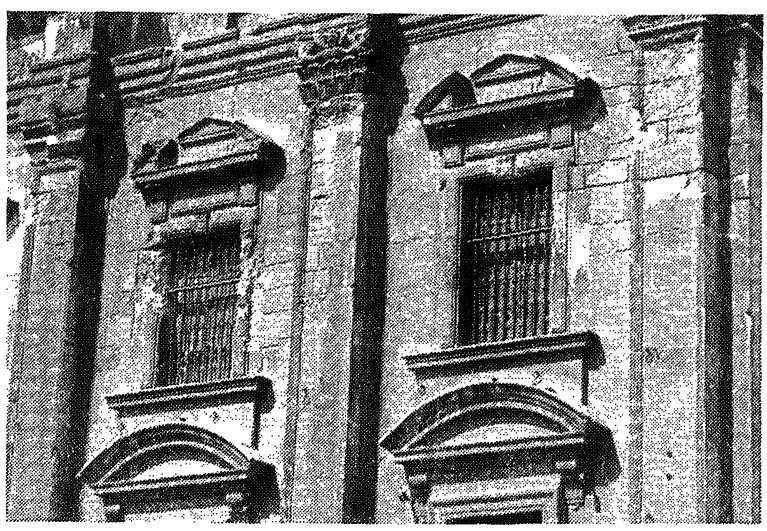

f) Arenizaciones diferenciales, más graves en los dinteles.

f) Differential arenizations, more serious on the lintels.

Figura 6.-Indicadores visuales de alteración. Fachada Este. 1. ${ }^{a}$ lámina.

Figure 6.-Visual indicators of deterioration. Eastern Façade. $1^{\text {st }}$ picture. 


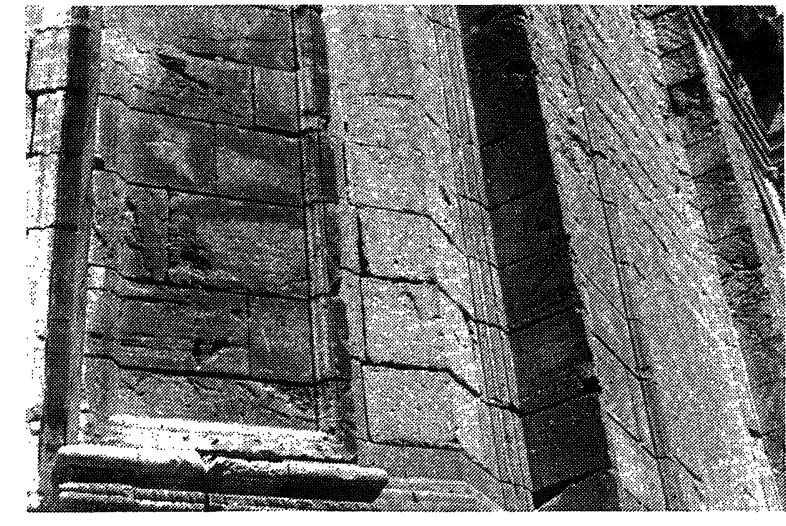

a) Picados y estriados en un lienzo.

a) Pitting and striations on a face.

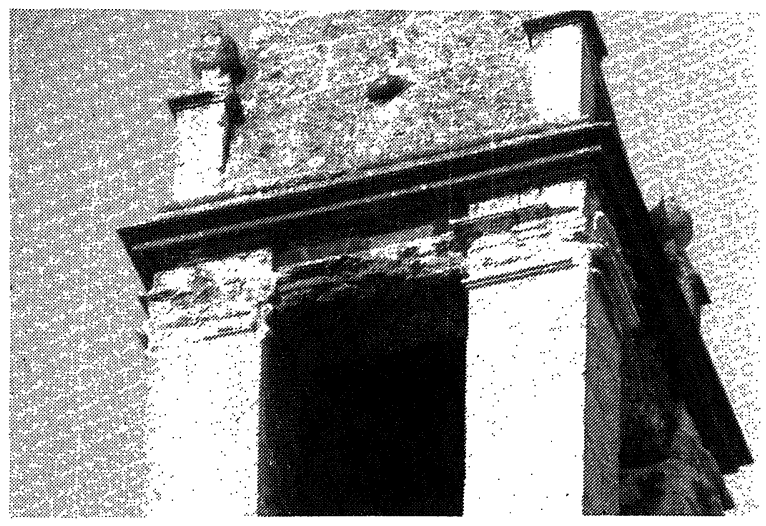

c) Arenizaciones y alveolizaciones en los aireados templetes.

c) Arenizations and alveolar erosions on windswept keeps.

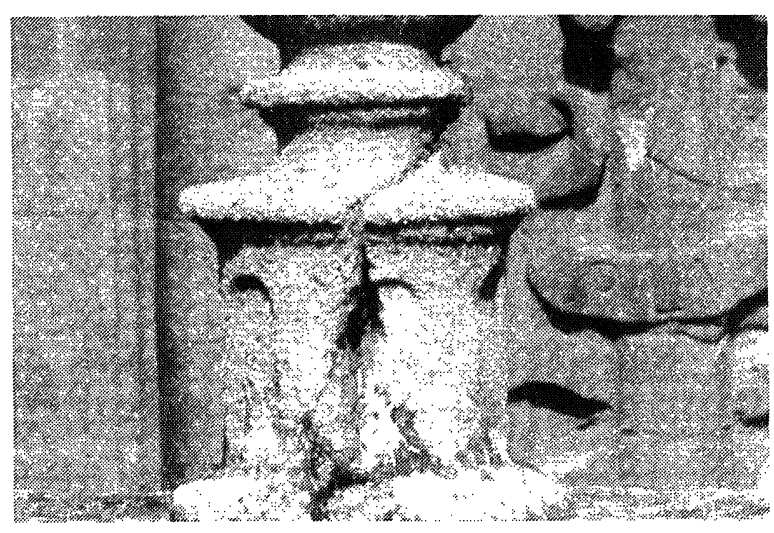

e) Fisuración por oxidacón de las espigas metálicas de sujeción.

e) Fissuring due to oxidation of the metal spike-holders.

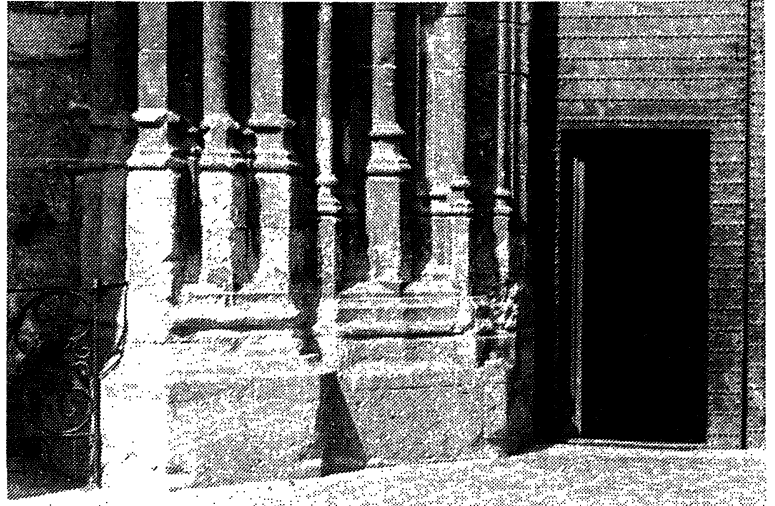

b) Alveolizaciones en zócalos.

b) Alveolar erosion on socles.

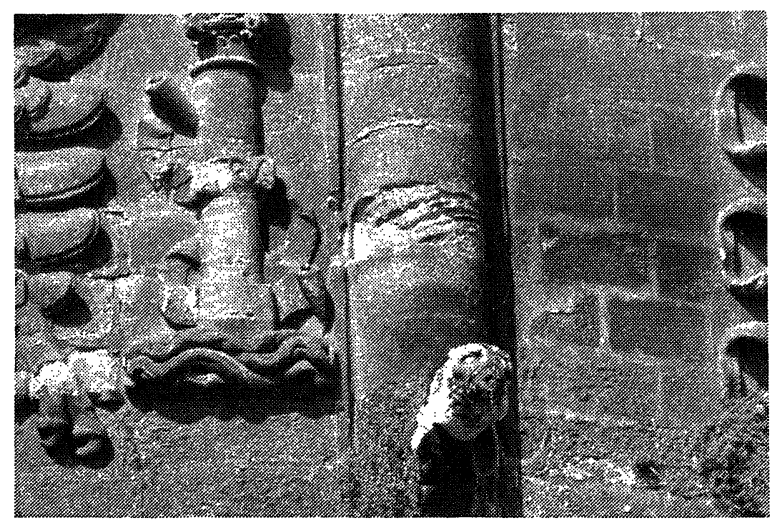

d) Estriado en un tambor.

d) Striation on a drum

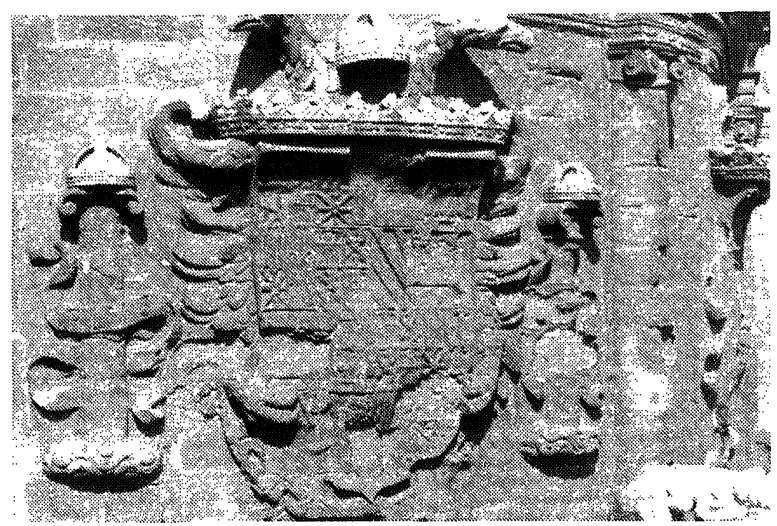

f) Fragmentaciones en los labrados de los escudos.

f) Spalling on the figured shields.

Figura 7.-Indicadores visuales de alteración. Fachada Este. 2. ${ }^{\text {I }}$ lámina.

Figure 7.-Visual indicators of deterioration. Eastern Façade. 2. ${ }^{\text {nd }}$ picture. 
de los cuales ya no existen (Figura 6 d, 1987); la Figura 6 e muestra el estado del último que aún queda. Otras arenizaciones de forma diferencial entre unos sillares y otros se presentan en el muro de la Sala Capitular, sobre todo en las pilastras, en el medallón y en las jambas de las ventanas (Figura $6 \mathrm{f}$ ).

Las alteraciones de picado se extienden por todo el muro del flanco Sur (Figura 7 a), así como en los zócalos de piedra de Morón de la puerta de Campanillas, donde también se dan alveolizaciones (Figura 7 b). No obstante, éstas son más profundas en los aireados torreones de la Capilla Real, en la parte superior de sus pilares y en los dinteles (Figura $7 \mathrm{C}$ ), así como en su balaustrada. En el mencionado muro son frecuentes también los estriados (Figura 7 a), prácticamente los únicos existentes salvo algunos otros de carácter episódico (Figura 7 d).

Al igual que ocurría en la fachada Sur, las espigas metálicas de sujeción de los remates de la balaustrada, al oxidarse han provocado la fracturación de muchos de ellos, formándose grandes fisuras y terminando con la caída de algunos de ellos (Figura 7 e). Los adornos que rodean al cupulín de la linterna han perdido en su mayoría la aguja en que terminan las bolas. Otras fracturaciones y fragmentaciones afectan a los escudos (Figura $7 \mathrm{f}$ ) así como a las cornisas y a aquellos elementos con gran superficie expuesta al medio ambiente.

En resumen en esta fachada vuelven a ser notorios los depósitos de inquemados, las costras y las placas biológicas. Las arenizaciones en las balaustradas son profundas. Las rupturas por expansión de espigas son frecuentes.

\subsection{Fachada Norte}

La piedra estructural de toda esta fachada es del tipo Puerto de Santa María, así como la de las cresterías y pináculos aunque con intercalaciones del tipo Espera. Los contrafuertes de la portada de la Concepción son también del Puerto, pero el lienzo frontal y la primera crestería son de caliza oolítica. Las tracerías de algunos ventanales y ciertas restauraciones son de caliza blanca compacta.

El Patio de los Naranjos protege a esta fachada de los humos del tráfico, por lo que el aire próximo a la fachada está menos contaminado.

Los agentes biológicos están muy extendidos por toda la fachada al ser ésta, por su arenizations of differential from between some ashlars and others are seen in the Sala Capitular wall, above all in the pilasters, medallion and window-posts (Figure 6f).

Pitting deteriorations are spread all over the wall of the South wing (Figure 7a) as well as in the socles, stone from Morón, of the

Campanillas gate where alveolar erosions also take place (Figure $7 b$ ). Nevertheless, these are deeper in the ventilated keeps of the Capilla Real, the higher part of their pillars and lintels (Figure 7c) and the balaustrades. In the aforementioned wall striations (Figure 7a) are also frequent, practically the only ones existing except for some others of incidental character (Figure 7d).

The oxidation of the metal spike-holders on the tips of the balaustrade, the same as has happened on the Southern facade, has provoked cracking in many of them, forming large fissures and some of them falling off (Figure 7e). The ornaments that surround the small dome of the lantern have lost the tips of their balls. Other cracking and spalling affect the shields (figure 7f) as well as the cornices and those elements with large surfaces exposed to the environment.

In summary, on this facade the deposits of unburnt materials (cracks and biological plaques) are again notorious. The arenization in the balaustrades are deep. The rupture due to expansion of spikes are frequent.

\subsection{Northern Façade}

The structural stone on this facade is from Puerto de Santa Maria although the crestings and pinnacles are intercalated with stone from Espera. The buttresses of the Portada de la Concepción are also Puerto Stone but the frontal stretch of wall and the first cresting are of an oolitic limestone. The traceries of some large windows and certain restorations are of a compact white limestone.

The Patio de los Naranjos protects this façade from the traffic so the air around this facade is less contaminated.

The biological agents are very widespread all over this façade as this, because of its 
orientación, la más umbría y húmeda de todas. Se presentan, fundamentalmente, de cuatro formas distintas: como estratos de cierto espesor y aspecto almohadillado formados por musgo, y que pueden arrancarse por simple frotamiento con los dedos; como películas, sobre todo donde existen depósitos de inquemados, en que éstos adquieren gran coherencia por el crecimiento de algas en su seno, y que suelen separarse como tales sin que obligatoriamente haya de verse afectada la piedra soporte; como costras (Figura 8 a) endurecidas por concreciones, en que la interfase está constituida simultáneamente por piedra y organismos biológicos y que cuando se separan lo hacen en forma de placas, arrastrando parte del material subyacente, dejando la piedra superficialmente arenizada; $y$, por último, como colonias independientes de líquenes, sobre todo en la caliza oolítica, ofreciendo así un típico moteado. Además de los agenes descritos, existen otros microorganismos no observables a simple vista y que su estudio exige un muestreo cuidadoso y posterior examen microbiológico en el laboratorio; en el otro extremo, el crecimiento de plantas superiores (Figura 8 b), cuya identificación ha de hacerse en época de floración, que actúan como factores de alteración, bien por el exudado de sus raíces, bien por las tensiones que generan al crecer éstas. Finalmente, son de destacar en esta fachada los abundantes depósitos de guano de palomino, que cubren abundantemente los baquetones de la portada de la Concepción (Figura $8 \mathrm{c}$ ). De todo ello se ha realizado un cuidadoso estudio (Ortega, 1988).

La protección del Patio de los Naranjos frente a los focos emisores afecta a la inmisión de partículas sedimentables, lo que se pone de manifiesto en el hecho de que son menores las deposiciones carbonosas, sobre todo en los niveles altos de la fachada. Sin embargo, los niveles bajos, más húmedos, adherentes de partículas y reactivos químicamente, poseen una fuerte pátina.

Al igual que en las otras fachadas son abundantes las disyunciones de placas acompañadas de arenizaciones (Figura $8 \mathrm{~d}$ ), en este caso con gran responsabilidad de los agentes biológicos; a veces la arenización alcanza gran profundidad de forma que, sobre todo en los elementos ornamentales, una simple presión de los dedos puede hacer que se separen fragmentos (Figura 8 e), o bien se pierdan las partes más angulosas (Figura $8 \mathrm{f}$ ). Como siempre, no faltan ejemplos de arenizaciones inducidas por el mal uso de morteros (Figura 9 a).

La mayor humedad contrarresta la menor aireación de esta fachada de forma que orientation, is the most shaded and humid. These are shown, fundamentally, in four different ways: as layers of a certain thickness and cushion-like appearance formed by moss and which can be torn off by simply rubbing with fingers; as films, above all where deposits of unburnt material exist, in which these acquire a great coherency due to the growth of algs inside and which are usually separated as such without the underlying material necessarily being affected; as crusts (Figure 8a) hardened by concretions, in which the interphase is simultaneously constituted by stone and biological organisms and which when separated do so in plaques, pulling off part of underlying material and leaving the stone superficially arenized; and lastly, as independant colonies of lichens, especially on oolitic limestone, so offering a typical spotting. Apart from these agents described other unseen micro-organisms exist and their study demands a careful sampling and a later microbiological study in the laboratory; on the other hand, the growth of higher plant-life (Figure $8 b$ ) whose identification has to be carried out at the time of flowering which, act as deterioration factors because of the exudation of their roots or due the tensions they generate on growing. Finally the abundant sea-bird dung deposits are outstanding which cover the mouldings of the Portada de la Concepción (Figure 8c). A careful study of this has already been carried out (Ortega, 1988).

The protection by the Patio de los Naranjos against the emitting focal points affects the immission of sedimentable particles which shows by the fact that the carbonaceous depositions are less, above all on the high levels of the façade. However, the low levels, more humid, adhesive of particles and chemically reactive, have a strong patina.

The disjunctions of plaques accompanied by arenizations (Figure $8 d$ ) are abundant the same as on other façades, in this case the biological agents being greatly responsible; sometimes the arenization is at such a great depth that, especially in the ornamental elements, a simple pressure of the fingers can make the fragments fall off (Figure 8e) or lose their more angulous parts (Figure $8 \mathrm{f}$ ). As always there is no lack of examples of arenizations induced by the bad use of mortars (Figure 9a).

The high humidity counteracts the lesser aeration of this façade so that pitting is also 


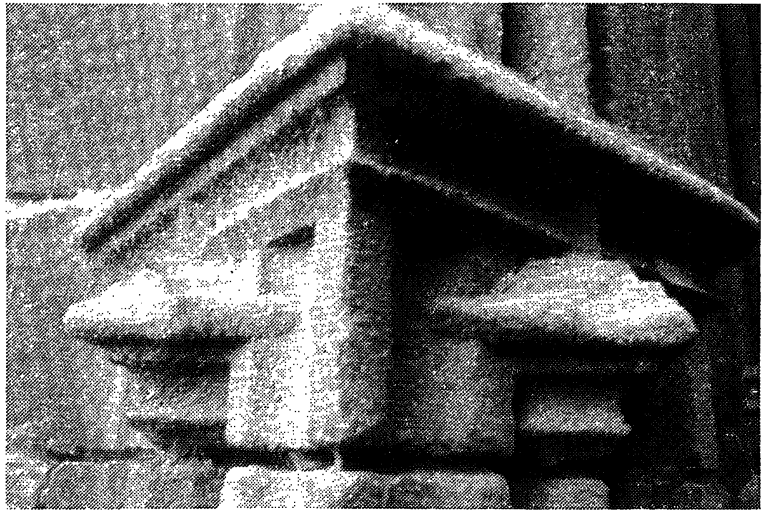

a) Costras biológicas.

a) Biological crusts.

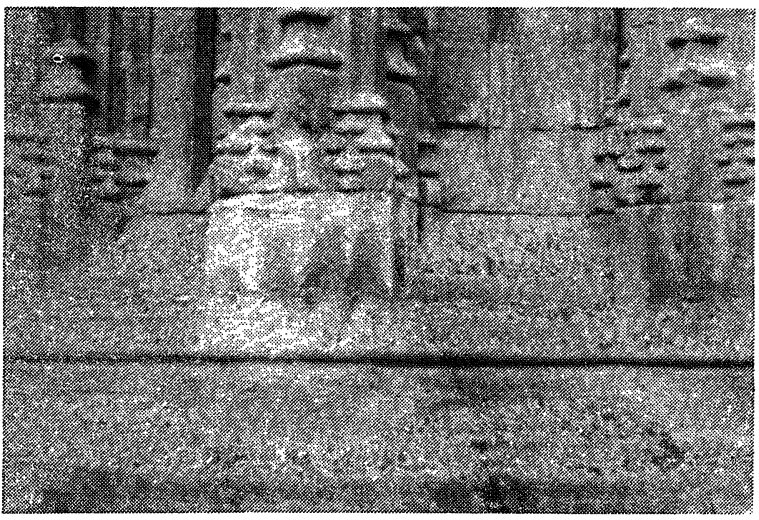

c) Depósitos de guano de palomas en la Portada de la Concepción.

c) Sea bird dung deposits on the Portada de la Concepción.

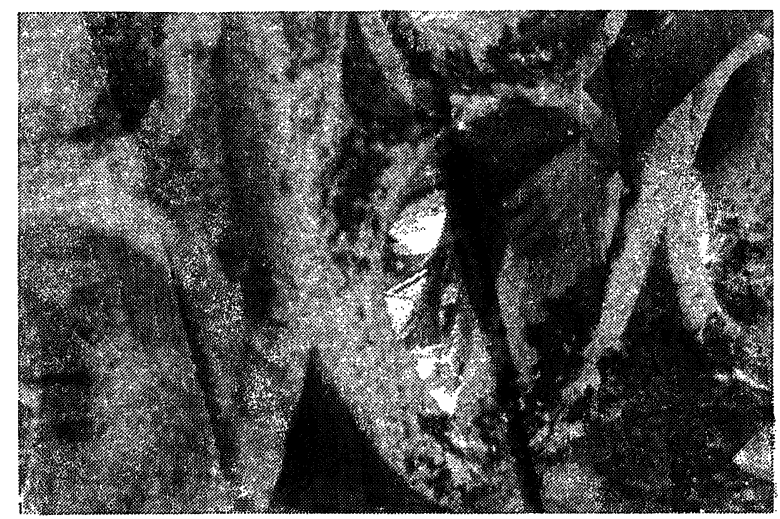

e) Placas biológicas y arenizaciones.

e) Biological plaques and arenizations.

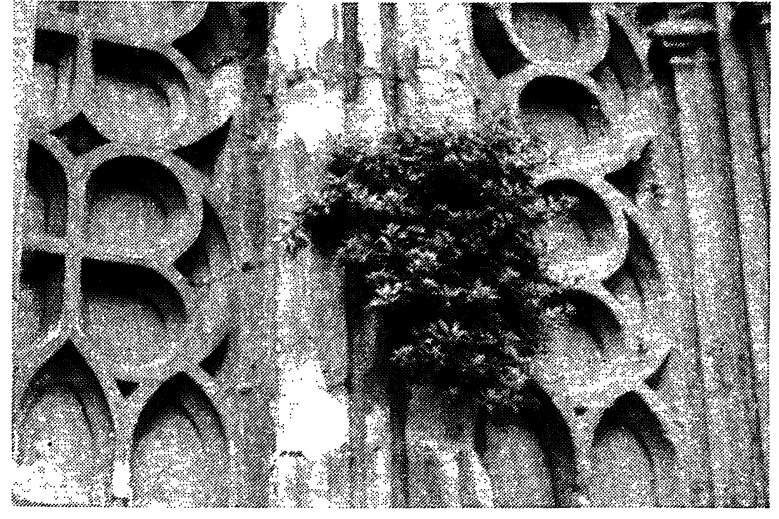

b) Plantas superiores.

b) Higher plant-lives.

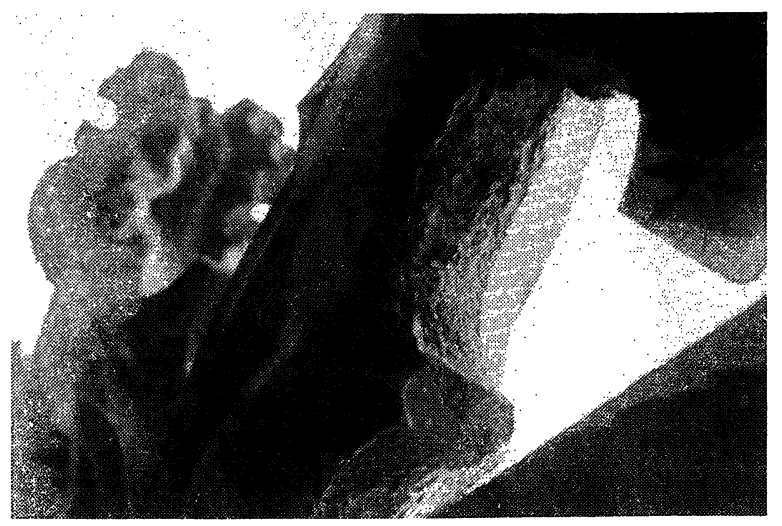

d) Disyunciones y arenizaciones en las cresterías.

d) Disjunctions and arenizations on crestings.

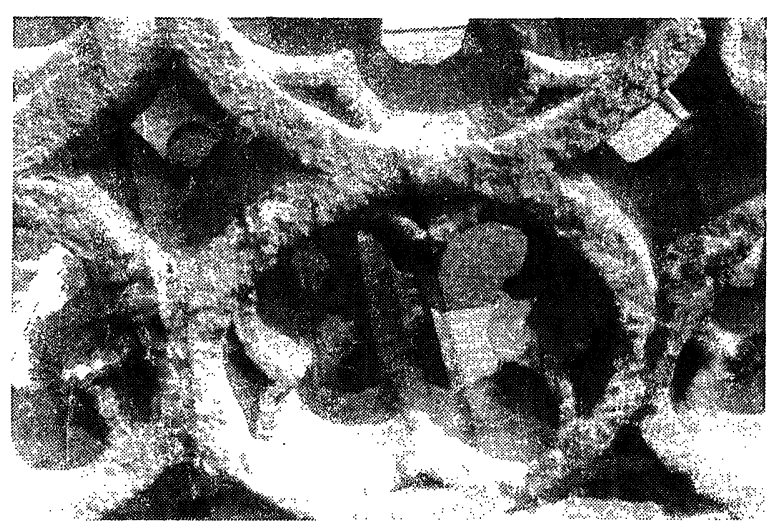

f) Arenizaciones en cresterías:

f) Arenizations on crestings:

Figura 8.-Indicadores visuales de alteración. Fachada Norte. 1. lámina.

Figure 8.-Visual indicators of deterioration. Northern Façade. 2. ${ }^{\text {nd }}$ picture. 


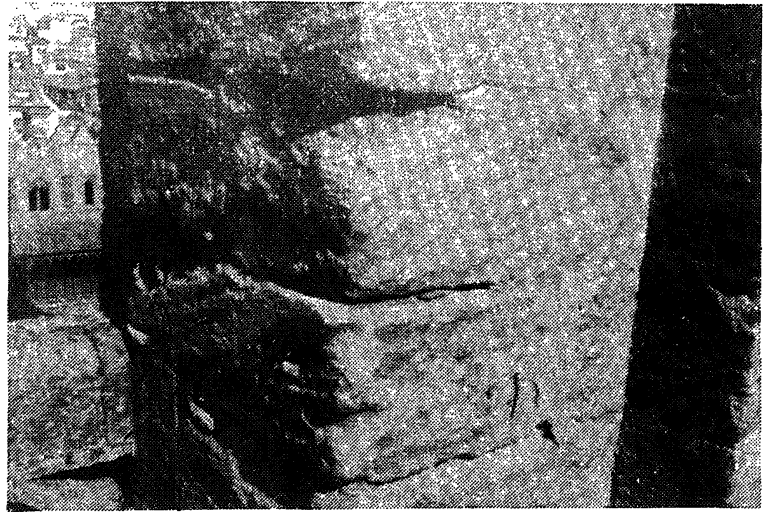

a) Arenización inducida por morteros.

a) Arenizations by mortars.

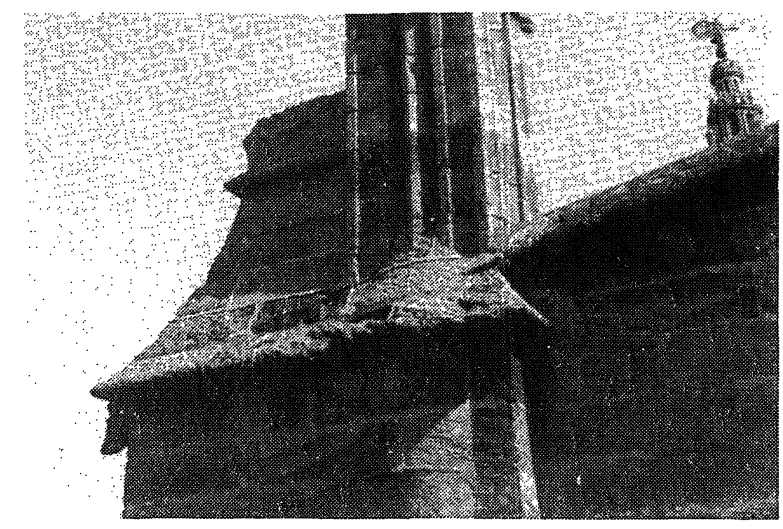

c) Picado y alveolización en las zonas más aireadas.

c) Pitting and alveolar erosion on more windswept areas.

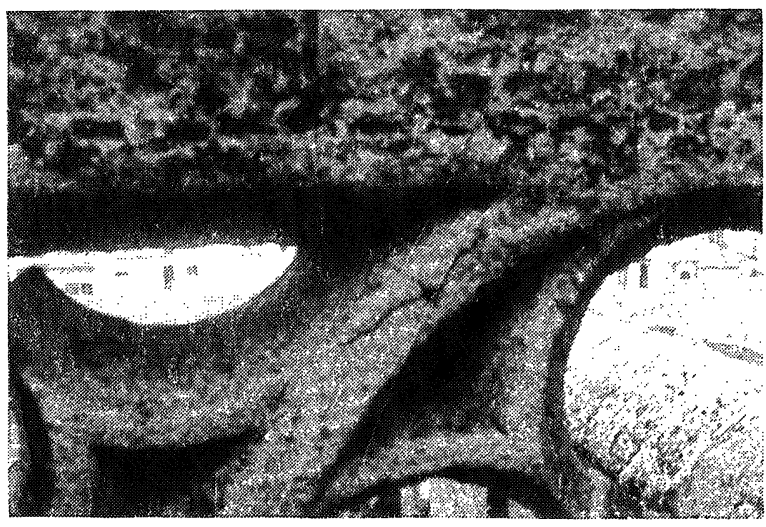

e) Fisuraciones producidas por la oxidación de clavos.

e) Fissuring due to nail oxidations.

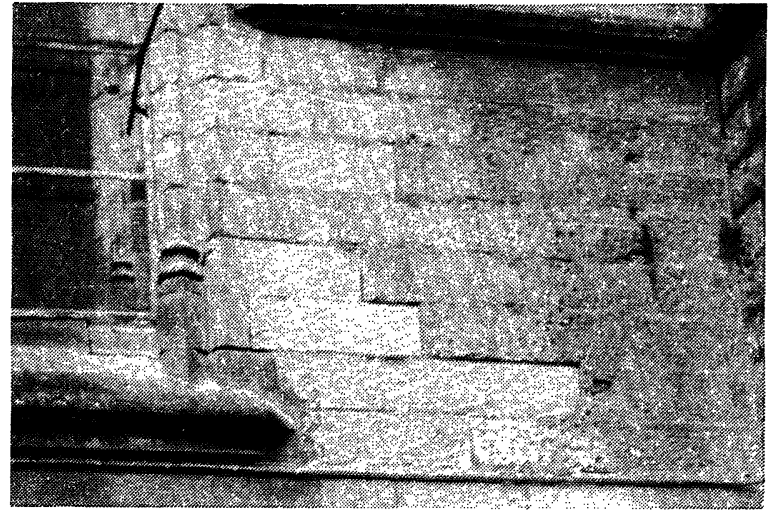

b) Picado en zonas húmedas de los paramentos.

b) Pitting on humid areas of faces.

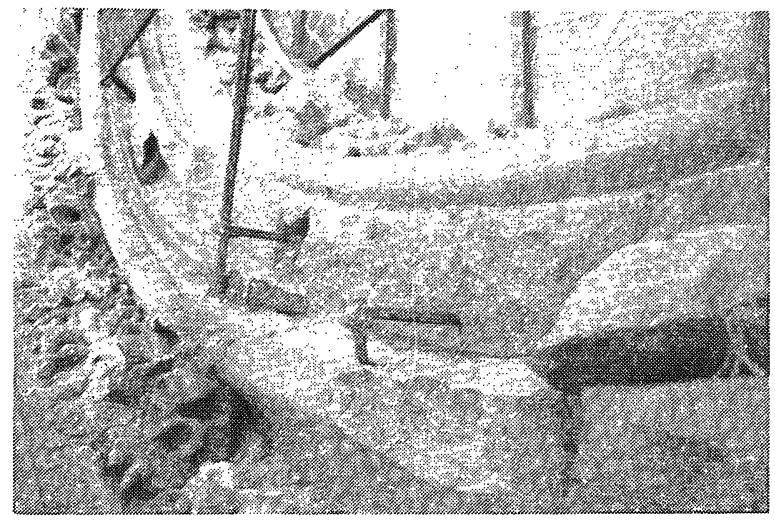

d) Fracturaciones y efecto de la oxidación de hierros.

d) Cracking due to iron oxidation.

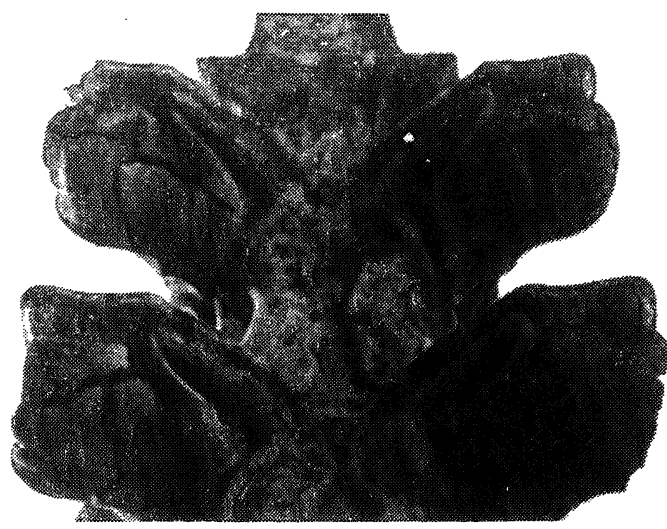

f) Fisuraciones producidas por expansiones térmicas.

f) Fissuring due to thermic expansions.

Figura 9.-Indicadores visuales de alteración. Fachada Norte. 2. a lámina.

Figure 9.-Visual indicators of deterioration. Northern Façade. 2. ${ }^{\text {nd }}$ picture. 
también abundan los picados (Figura 9 b), que se convierten en alveolizaciones en los niveles altos (Figura $9 \mathrm{c}$ ).

También son importantes las rupturas originadas por la expansión de hierros embutidos en la piedra al oxidarse. Es significativo el hecho de que este fenómeno queda limitado a los alrededores del elemento metálico en el caso de la porosa calcarenita del Puerto (Figura 9 d) mientras que en la compacta caliza oolítica las fracturas pueden alcanzar grandes distancias, como se vió en la fachada Sur (Figura 5 a). En este litotipo se han encontrado aquí fisuraciones originadas probablemente por expansiones térmicas, en elementos muy expuestos al sol (Figura $9 \mathrm{f}$ ).

En resumen, lo más destacable en esta fachada son los agenes biológicos y, por tanto, los indicadores a ellos asociados: placas, costras, ennegrecimientos, depósitos, etc. Las arenizaciones de los labrados más agudos de la portada son ya graves y afectan fuertemente a su estética. abundant (Figure 9b) which is converted into alveolar erosions at higher levels (Figure 9c).

The ruptures originated by the expansion of inlaid irons in the stone on oxidising are also important. it is significant that this only occurs in a limited area around the metallic element in the case of porose calcarenite from the Puerto de Santa María while in the compact oolitic limestone the cracks can reach great distances as was seen on the Southern façade (Figure 5a). Fissuring probably originated by thermic expansion has been found in this lithotype in the elements well-exposed to the sun. (Figure 9f).

In summary, the most outstandig feature on this façade is the biological agents and therefore, the indicators associated with them: plaques, crusts, blackening, deposits, etc. The arenizations of the sharper figures of the portal are now very serious and affect their esthetics seriously.

\section{BIBLIOGRAFIA}

- ALCALDE, M. et al:: La Catedral de Sevilla. Estudio de su estado actual de deterioro y métodos para su conservación. Premio Ciudad de Sevilla. Ayuntamiento de Sevilla. 1984.

- ALCALDE, M.: Sintomatología de alteraciones de las Catedrales de Sevilla, Cádiz y Almería. Ed. Universidad de Sevilla. 1990.

- BELLO, M. A.: Caracterización y estado de alteración química de los materiales empleados en la construcción de la Catedral de Sevilla. Tesis Doctoral. Universidad de Sevilla. 1988.

- Centro Meteorológico Zonal de Sevilla. Datos meteorológicos. 1985.

- ESBERT, R. M. et al.: Caracterización petrofísica y alterabilidad de las piedras de la Catedral de Sevilla. Materiales de Construcción, n. 210, vol. 38, 5-23. 1988.

- FALCON, T.: La Catedral de Sevilla, estudio arquitectónico. Ayuntamiento y Diputación Provincial. Sevilla. 1980.

- FONT, I.: Climatología de España y Portugal. INM. Madrid. 1983.

- MARTIN, A.: Ensayos y experiencias de alteración en la conservación de obras de piedra de interés histórico artístico. Ed. Ceura. 1990.

- PEREZ DE LEON, B.; CORTES, V.: Emisiones e inmisiones de $\mathrm{SO}_{2}$ y humos en Sevilla. Publicaciones Universidad de Sevilla. 1986

- USERO, J., et al: Estudio de la contaminación atmosférica de la ciudad de Sevilla por partículas sedimentables. I. Fracción insoluble. Ing. Quím. 176, 149-153. 1983. II. Fracción soluble. Ing. Quím. 177, 113-116. 1983.

- VILLEGAS, R.: Estudio de la alterabilidad y respuesta a tratamientos de conservación de los principales tipos de piedra utilizados en catedrales andaluzas. Ed. Universidad de Sevilla. 1990. 